\title{
Effect of Branch Expansion on Cost Efficiency of Ethiopian Commercial BANKS. (Stochastic Cost frontier Approach)
}

\author{
Mache Tesfay Hailu (M.Sc) student at Raya University,Ethiopia, Manager at Hibret Bank S.C. P.O.BOX 77
}

\begin{abstract}
Banks are a vital parts of a nation's economy that catalyzed Economic growth through facilitate spending and investment in the economy.Bank institutionis one and the top from the major financial institutions in Ethiopia.The number of all branches of the industry including public banks increased from year to year aggressively.Thus, the overall objective of this study was to investigate effect of branch expansion on cot efficiency Ethiopian commercial banks.Accordingly, from the population, Commercial banks operating in the country a total of 18 , among these, 2 public and 16 private commercial banks (a total of 14 commercial banks) were included in the study period 2010/11-2018/19 based on non-probability, purposefully sampling method. The research used theprice of labor, prices of capital,Number of branches, annual inflation rate, real GDP growth, Total loan output, management performances, market share, capital adequacy ratio,liquidity risk, prices of deposit and total securities variables to measure cost efficiency. To this end, the study used secondary data from the NBE, balance sheets and income statements of individual commercial banks obtained from the period from to 2010/11 to 2018/9. Then nine years' panel data of bank levelvariables has been collected and analyzed using stochastic cost frontier regression analysis. As a resultthe researcher concluded that stochastic frontier model as appropriate to represent inefficient operation among the commercial banks of Ethiopia . The Ethiopian commercial banks expanded their branches throughout the country's territory; most of the bank branches were opened.Despite the various challenges, banks preferred to go ahead with its plan to open more branches to reach customers. However their cost efficiency had been decreased as of aggressively opened branches in the study years.Accordingly the analysis result Zemen bank was the most cost efficiency and become the best practiced bank and CBE the most inefficiency bank and in reverses also characterizes in branch expansion profile.The researcher recommended thatEthiopianbanking institutions should continue to innovate so as to reduce their cost inefficiencies. Moreover, NBE and government stand towards policy that forbids foreign banks entry, the Reserve required ratio amount, and competition environment and policy in opening branches must revised.
\end{abstract}

Keywords: Branch expansion, cost efficiency, Ethiopian commercial banks

DOI: $10.7176 / \mathrm{RJFA} / 12-9-04$

Publication date:May $31^{\text {st }} 2021$

\section{Introduction}

Worldwide financial services industry is changing rapidly and is becoming more competitive. Over the last few decades, around the world the banking sectors have gone through drastic changes in terms of financial globalization and technological competition (Khalil et al, 2014 ,p 111). The importance of commercial banks to the socioeconomic development of some countries cannot be ignored, from both developed and developing countries banks have shown a significant role in the development and growth of economy by insuring prudent allocation of resources as well as their efficient utilization. However,the banking industry in low-income SSA countries is generally not performing adequately.

Banks, insurance companies and micro-finance institutions are the major financial institutions in Ethiopia. The number of banks operating in the country in 2010/11 reached 16, of which 13 were private and the remaining three states owned. All the banks expanded their branch network during the review year. As a result, 289 new branches were opened raising the total number of branch banks across the country to 970 of which total Public Bank 483 and total Private Banks 487(NBE, 2010/11).

Today the number of banks operating in the country reached 19: three governmental and 16 privately owned banks. Though, after March 09, 2016 the construction and business bank (CBB) merged with the dominant bank commercial bank of Ethiopia (CBE) their system, finances and all assets. There by, number of banks operating in the country would reduce 18 commercial banks in which 2 of them are owned by the state and the remaining 16 are private commercial banks. The number of total banks branch in the country reached to 4,757.As a result, bank branch to population ratio increased to 1: 20,286.55 people per branch (NBE, Annual Report, 2017/2018).Moreover, the Ethiopian Commercial banks opened 807 new branches in 2018/19 alone which increased the total number of branches to 5,564 from 4,757 a year ago (NBE, 2018/19,P 5).

Undoubtedly the banking industry in Ethiopia is underdeveloped and therefore there is an all immediate need to embark on capacity building arrangements and modernize the banking system by employing the state of the art technology being used anywhere in the world. A bank may pursue many goals but profit efficiency is obviously its ultimate goal and the cost efficiency is an important means for achieving long-run profit efficiency. 
Since the cost efficiency of the banking industry is influenced by the overall financial markets stability and financial intermediation cost. With a growing international trades and international relations, the current banking system is short of providing dependable services (Shashigo, 2016).

The Ethiopian banking sector is one of the repressed and protected sectors in the Ethiopian economy that has been regulated until the regime change took place in 1992. However, the sector is only allowed to domestic investors only by inhibiting entry of foreign banks (Gezae, 2015,p4). More over, the reforms introduced in the bank sector, the financial sector still remains to be undiversified in types of ownership, market share and financial instruments.

Despite the prevailing improvement in branch expansion, Ethiopia remains one of the under-banked economies even at sub-Saharan African countries standard (Teklebeirhan, 2008). Moreover, despite the various challenges, banks preferred to go ahead with its plan to open more branches to reach customers(HAILU, 2014). The expansion of branches is the main reason for staggering increase in loans, advances, and deposits. This is certainly a bad news for banks, especially for younger ones, since increasing the number of branches to mobilize deposits is now becoming compulsory in order to survive in the business, seriously shaken by a directive of the National Bank of Ethiopia (NBE) forcing banks to expand their branch. In addition, the stiff competition in the industry also pushes to expand their reaches to potential clients(Mesfin, 2009).

Question of efficiency has long been a challenge for the financial service any industry. Cost management is not only about reducing expenses but also about generating more revenue per unit of cost. Ethiopian banks vary widely in their commitment to cost management, and competition from non-bank institutions and banks expanding into new markets. This situation is putting strong pressure on Ethiopian commercial banks to improve their earnings and to control costs. Thus the main stream of prior studies in banking efficiency measurement concentrates on loan management, bank size, human resources bank managers and personnel, growth level and the ownership(a M.Y. Arafat et al, 2013,p 16).

Many studies had been carried out using frontier approaches to measure banking efficiency, focused mainly on the USA and other developed countries(Shashigo, 2016).In Ethiopia, in recent years, researchers have started to examine the efficiency of banks. Muluneh (2006) employed the SFA to examine the determinants of cost efficiency for six private banks by using quarterly data over the period 1994-2001.Eskindir (2013) uses the stochastic frontier analysis to investigate the cost efficiency of commercial banks based on their ownership during the period 2007-2012. The result shows private commercial banks are more cost efficient than state owned bank. Emishaw (2016) employed the SFA to examine the determinants of cost efficiency for twelve Commercial banks by using unbalanced panel data over the period 2000-2013. The results show that Ethiopian banks were on average inefficient.

Most of the previous studies limited their investigation only for cost efficiency and neglect the causes of cost efficiency; they cover a short period of time and compare efficiency of banks based on their ownership and usednon-parametric models to estimate bank efficiency level. Regarding this matter, the literature has foundEthiopian banks are on average inefficient. Still the study reveals ownership (state-owned and private), size, structure and related input output variables specification, and researcher addsnumber of bank branches to check if cost efficiency depends branch expansion.

To date, there had been limited published studies on effect of branch expansion on bank cost efficiency in the case of Ethiopian commercial banks that have driving forces of an economy. So this research was motivated by both the importance of efficiency measurement and unavailability of studies in Ethiopiancontext in the specified topic using the parametric model. That is why, the researcher provoking to studyobjectively the topic to reveal the branch expansion profile, the level of cost efficiency among selective commercial banks of Ethiopia. Final objective would analyzed therelationship between cost efficiency of commercial banks and branch expansionin Ethiopia for the last over-nine years.

\section{Literature Review}

\section{Chapter 1 2.1. Definition of Efficiency}

Efficiency is measured with respect to an objective for instance maximization of output, maximization of profits, or minimization of costs. That is, efficiency is the ability to avoid wasting materials, energy, efforts, money, and time in doing something or in producing a desired result. According to Kablan (2010) banking sector efficiency measures how close a decision making unit gets to its production possibility frontier, composed of sets of points that optimally combine inputs in order to produce one unit of output. Similarly, Loretta (2003) defined efficiency as a measure of the deviation between actual performance and desired performance. According to Nader et al. (2017) classified banking efficiency using the following five types.

\section{Chapter 2 2.1.1. Technical efficiency}

Technical efficiency is the effectiveness with which given set of inputs are used to produce an output. Banks' technical efficiency is defined as the difference between observed quantity of input and output variables with respect to optimal quantity of input and output variables. Technical efficiency in production unit refers to the 
achievement of the maximum potential output from given amounts of factor inputs taking into account physical production relationships (Farrell, 1957).Technical efficiency is most frequently associated with the role of management in the production process. Efficiency is also doing a task in the cheapest possible way of producing a given level of output from the lowest possible combination of inputs or producing the maximum output given the level of inputs employed. It reflects the ability of firm or decision making unit to attain the maximum output from a given set of input. Thus, a technically efficient production could produce the same output with less of at least one input, or could use the same input to produce more output (Green, 1993).The level of technical efficiency of a particular firm is characterized by the relationship between observed production and some ideal or potential production. The measurement of firm's specific technical efficiency is based on deviations of observed output from the best production of efficient frontier. If a firm's actual production point lies on the frontier, it is perfectly efficient and if it lies below the frontiers, then it is called technically inefficient(Tesfaye $\&$ Abdurezak, 2017).

Chapter 3 2.1.2. Scale efficiency

Scale efficiency is the ability of bank to reach the optimal operations. The bank has scale efficiency when it operates in the range of constant returns to scale. Scale efficiency often arises from the ability of large firms to allocate fixed costs such as advertising expenses or cost of technology across a greater volume of output. It also shows whether the decision making units (say banks) operate at the minimum of their long run average cost curve. It focuses on technical efficiency which is the ability of a bank to produce maximal output from a given set of inputs over a certain time period(Adongo, 2005). Scale economies are usually measured using data on all banks in the sample rather than just using the data on all of the banks. Scale Economies theoretically apply only to the production possibilities frontiers where firms are fully X-Efficient and minimize costs for every scale of output(Tesfaye \& Abdurezak, 2017).

Chapter 4 2.1.3. X-Efficiency

$\mathrm{X}$-inefficiency is loss at which a bank is operating or deviation from the optimum(Leibenstein, 1966).Xinefficiency is an intra-firm inefficiency or the deviation from the production efficient frontier which depicts the maximum attainable output for a given level of input. This inefficiency can arise from management practice and the environment as well. Berger et. al., (1993) describe X-inefficiency as a variance from the efficient frontiers set by the best practice or benchmark firm. It incorporates two components, i.e. technical and allocative inefficiencies (Allen \&Rai, 1996). According to Farrell (1957), technical inefficiency occurs due to sub optimal usage of input leading to waste, while allocative inefficiencies arise from inappropriate mix or composition of inputs using inefficient business process. Both inefficiencies are attributed to employee, management or environment factors.

\section{Chapter 5 2.1.4. Scope efficiency}

Scope efficiency occurs when the bank operates in different diversified locations.Scope efficiency may result from sharing information such as knowledge of customer's habits across products line. It refers to change in product mix related to cost. It occurs when it is more economical to produce two or more products jointly in a single production unit than to produce the products in separate specializing firms. Scope economies could emanate from two sources: i) spreading of fixed cost over an expanded product mixes and ii) cost complementarities in producing different products. Spreading fixed cost occurs, for example, when the fixed capital of a bank or its branches is more fully utilized by issuing many types of deposits to local residents than building separate offices to fulfill the separate demands for transactions accounts, saving accounts, consumer loans and business loans. Such economical spreading of costs occur to the extent that the production of different types of services requires much the same type of computer, accounting system and other fixed inputs of a branch and there is insufficient local demand to justify a full specialized branch for each of the services. In contrast, cost complementary between deposits and loans occur, for example, when the payment flow information developed in producing deposit services is used to reduce the costs of acquiring credit information and monitoring loans to the same customer. However, there is problem in applying the translog cost/profit function or other multiplicative specification to evaluate scope economies(Tesfaye \& Abdurezak, 2017).

Chapter 6 2.1.5. Allocative Efficiency

Allocative efficiency measures a bank's success in choosing an optimal set of inputs with a given set of input prices. Allocative efficiency, or as Farrell called it price efficiency, refers to the ability of a firm to choose the optimal combination of inputs given input prices (Farrell, 1957). If a firm realizes both technical and allocative efficiency, it is then cost efficient (overall efficient). Allocative efficiency measures the skills in achieving the best combination of inputs by taking in to account their relative prices or produces the right mix of outputs given the set of prices (KumhakerandHevell, 2000). It reflects the capability of a firm to utilize input in optimal proportion, given their respective prices and the production technology. In other words, allocative efficiency refers to whether inputs for a given level of output and set of input prices are chosen to minimize the cost of production; assuming that the firm being examined is already fully technically efficient. It operates on the least cost expansion path, i.e. the point where the marginal rate of technical substitution is equal to input price ratio. 
This is very important when one input can be substituted for another in the process of production (Tesfaye B.L, 2017,P 36).Thereby, in short allocative efficiency categorized in to two as reveals below.

\section{Chapter 7 2.1.5.1. Cost Efficiency}

Cost efficiency is the ability of a bank to provide services without wasting resources as a result of technical or allocative inefficiency. Cost efficiency gives a measure of how close a firm's cost is to what a bestpractice firm's cost would be for producing the same output bundle under the same conditions. It is derived from a cost function in which variable costs depend on the prices of variable inputs, the quantities of variable outputs and any fixed inputs or outputs, environmental factors, and random error.(Loretta J. Mester, july 2003).The concept of cost efficiency is rooted in the neoclassical micro economic theory, whichfocuses on resource allocation and utilization. It advocates non-wastage of resources byemphasizing cost reduction (Beletew, 2016).

\section{Chapter 8 2.1.5.2. Profit Efficiency}

Profit efficiency is a broader concept than cost efficiency since it takes into account the effects of the choice of vector of production on both costs and revenues and depending on whether or not market power is taken into account.Two profit functions can be identified: depending on whether or not there is market power: the standard profit function and the alternative profit function.Profit efficiency concept is superior to cost efficiency concept for evaluating the overall performance of firms. This is because profit efficiency accounts for errors on the output side as well as those on input side. Besides, profit efficiency is based on the more accepted economic goal of profit maximization, which requires that the same amount of managerial attention be paid to raising a marginal dollar of revenues as to reduce a marginal dollar of costs(LELISSA, 2017).

Table 0:1 List of Banks in Ethiopia

\begin{tabular}{|l|l|l|l|l|}
\hline S.No & Name of the bank & Year Established & Number of Branches & Ownership \\
\hline 1 & National Bank of Ethiopia & 1931 & Central bank & State \\
\hline 2 & Commercial Bank of Ethiopia & 1963 & 1578 & Public \\
\hline 3 & Development Bank of Ethiopia & 1970 & 136 & Public \\
\hline 4 & Awash International Bank & 1994 & 423 & Private \\
\hline 5 & Abay Bank S.C & July 14,2010 & 200 & Private \\
\hline 6 & Addis International bank & Jan 31,2011 & 130 & Private \\
\hline 7 & Bank of Abyssinia & 1996 & 353 & Private \\
\hline 8 & Berhan International Bank & 2010 & 217 & Private \\
\hline 9 & Bunna International Bank & 2009 & 209 & Private \\
\hline 10 & Cooperative Bank of Oromia & 2005 & 405 & Private \\
\hline 11 & Dashen Bank & 1995 & 421 & Private \\
\hline 12 & Enat Bank & Nov14,2013 & 102 & Private \\
\hline 13 & Lion International bank & 2006 & 235 & Private \\
\hline 14 & Nib International Bank & 1999 & 280 & Private \\
\hline 15 & Oromia International Bank & 2008 & 277 & Private \\
\hline 16 & Debub Global bank & April 20,2012 & 135 & Private \\
\hline 17 & United Bank & 1998 & 294 & Private \\
\hline 18 & Wegagen Bank & 1997 & 355 & Private \\
\hline 19 & Zemen Bank & 2009 & 44 & Private \\
\hline Total & & & 4953 & \\
\hline
\end{tabular}

Source: National Bank of Ethiopia (online list of Banks in Ethiopia on 2019)

\section{Chapter 9 2.2 Conceptual Frameworks Summary and Research Gap}

This framework had been focusedfirstly; it had included variables other than the variables included by other scholars in Ethiopia context for measuring bank cost efficiency. Secondly, the study hadpresented commercialbanks branch expansion and cost efficiency from 2010/11 to 2018/19 year. Thirdly, the study tried touse a parametric measurement unlike earlier studies were based on non-parametric techniques. Therefore, the conceptual framework guiding this study had been presented in the figure depicted follow. 


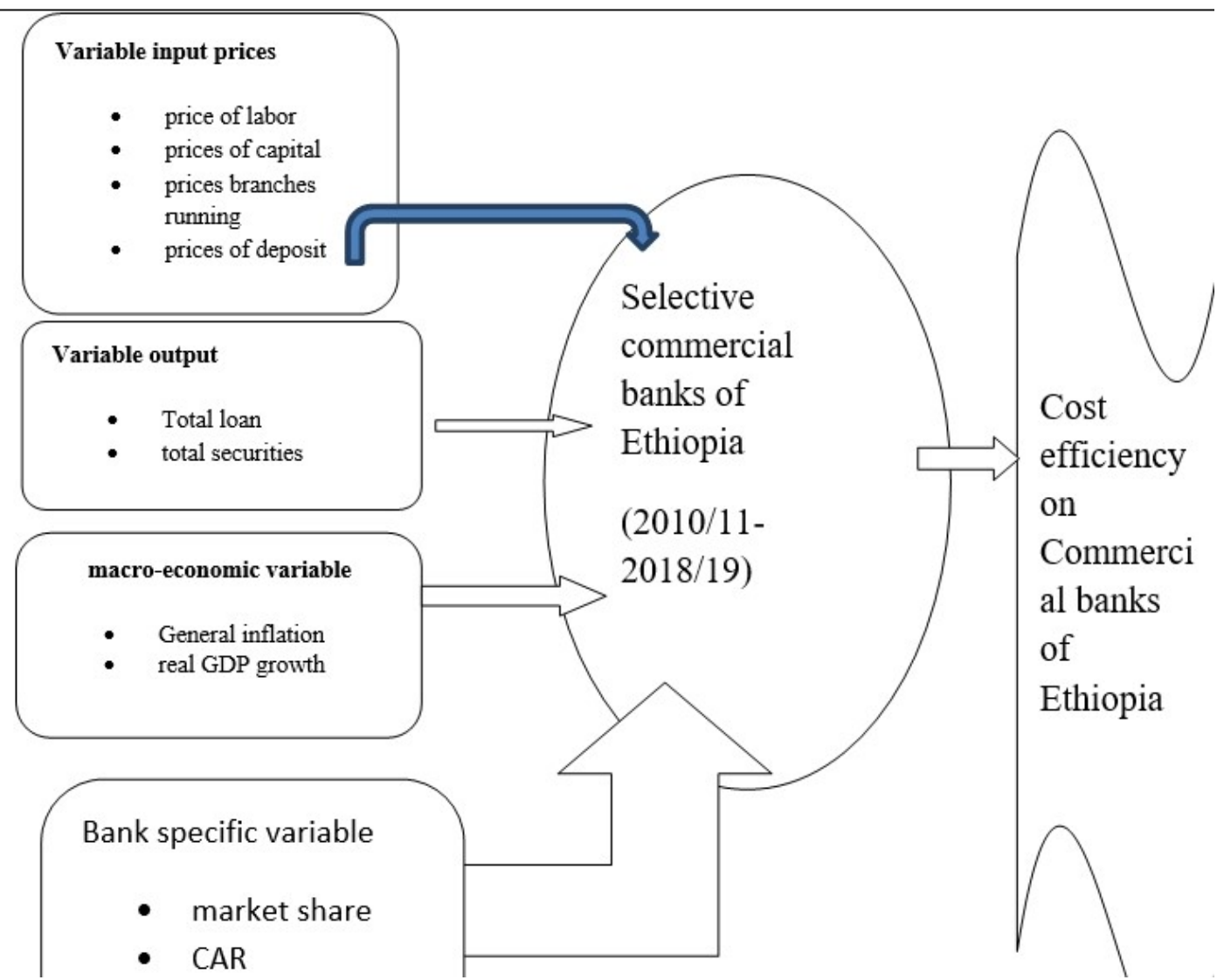

Figure 0:1 Conceptual frame work of the study

Sources: author own conceptualization

\section{Research Methodology}

\section{Chapter 10 3.1. Research Design}

In this study, a sort of explanatory research designwere used to explain the relationship between commercial bank's cost efficiency and branch expansion using quantitative data from the annual report of Ethiopian commercial banks and National bank of Ethiopia.

\section{Chapter 11 3.2 Target Population and}

This study intended to examine the effect ofbranchexpansion on cost efficiencyofEthiopian commercial banks. Since currently, in Ethiopia there are two public-owned and sixteen private commercial banks which are operating throughout the country. According to Sekaran (2003), since Population means the entire group of people, events, programs or things of interest that the researcher needed to investigate. Thereby, thetarget population of the study would be the Commercial banks registered by NBE (see online list of Banks in Ethiopia on June30, 2019, table 2.1)

\section{Chapter 12 3.2.1. Sample Design Sampling Technique}

Accordingly, from the population, Commercial banks operating in the country a total of 18, among these, 2 public and 16 private commercial banks (a total of 14 commercial banks) were included in the study period 2010/11-2018/19 based on non-probability, purposefully sampling method. Because of the short history of private commercial banks impossible to find data, the researcher obligated to exclude banksnamely, Addis International bank, Debub Global Bank and Enat bank based on their years of establishment and unavailability of nine year panel data.In addition to that data on the development bank of Ethiopia is not fully reportedto organized data on the required variables for the study period is out of the study.

\section{Chapter 13 3.3. Data Sources andMethod of Data Collection}

Since banks adequately capture past financial performance of the Ethiopian commercial banks under their domain. As a result, the study used secondary sources of data from the balance sheets and income statements of individual commercial banks and NationalBankofEthiopia obtained from the period from to $2010 / 11$ to 2018/19. Accordingly, audited financial statements of 14 commercial banks had gathered from the published annual reports of individual banks, and various publications of national bank Ethiopiato achieve the objective of the 
study.

\section{Chapter 14 3.4. Methods of Data Analysis}

Basically the analysis and presentation of the study was quantitative. In the first part, the researcherused descriptive statistics (percentages, frequency, and means); and were presented using Tables and graphs. Secondly, to reveal effect of branch expansion on cost efficiency of commercial banks of Ethiopia would analyze, in the econometric analysis part, using thecoststochastic frontier regression model over 2010/112018/19 FY.The major advantage of using SFA method is it allows the measurement error and provides a firm specific efficiency estimate. Moreover, due to the growing importance to utilize software packages, the researcher would analyze the data with the help of Stata Version 14.

\section{Chapter 15 3.5. Econometric Model Specification}

The researcher to estimate cost efficiency score used that, constant returns to scale assumption.Then estimation of cost efficiency requires the specification of the prices of inputs, out puts and macro-economic variables. Then, Cost Efficiency (CE) is measured relative to the efficient cost frontier. According, Berger et al. (2008)CE is derived as the ratio of the minimum cost to the actual cost incurred. The scientific models more significant for my study were as following:

$$
\text { Cost Efficiency }(\mathrm{CE})=\frac{T C}{T C}
$$

Where, $\mathrm{TC}^{*}=$ minimizes costs for the input output level.

$\mathrm{TC}=$ the total cost incurred in producing a given output level.

Failure to attain the cost frontier may be due to either technical or allocative inefficiency (or both). As the cost frontier is deterministic, such a formulation ignores measurement errors and other sources of statistical noise. All the deviations from the frontier are attributed to inefficiency. Cost efficiency is derived from a cost function as a single-equation of a stochastic cost function model for a panel data is presented below (Joshua, 2011 p,42).

$$
\text { Ln TCit }=f(\text { Qit, Wit; } \beta)+\text { Vit }+ \text { Uit }
$$

$\mathrm{i}=1,2,3$ . $\mathrm{N}$

$\mathrm{t}=1,2,3 \ldots \ldots \ldots \ldots \ldots \ldots \ldots \ldots \ldots \ldots$

Where $\mathrm{Ln} \mathrm{TC}_{\mathrm{it}}$ is the logarithm of the total cost of bank $\mathrm{i}$ at time $\mathrm{t} ; \mathrm{f}\left(\mathrm{Q}_{\mathrm{it}}, \mathrm{W}_{\mathrm{it}} ; \beta\right)$ is the deterministic kernel of the cost frontier; $\mathrm{Q}_{\mathrm{it}}$ and $\mathrm{W}_{\mathrm{it}}$ are the vector outputs and input prices in the logarithmic form of bank $\mathrm{i}$ at time $\mathrm{t}$; $\mathrm{i}$ and $\mathrm{t}$ represent the total number of firms and period considered in the study respectively; $V_{\text {it }}$ is a two sided normal disturbance term with mean of zero and variance, $\delta v^{2}$. This represents the effects of noise, and $U_{\text {it }}$ is a nonnegative random disturbance term capturing the effects of the cost efficiency and is usually assumed as a halfnormal distribution, $\mathrm{N}+\left(0, \delta \mathrm{u}^{2}\right) . \mathrm{V}_{\text {it }}$ and $\mathrm{U}_{\text {it }}$ are independently distributed from each other.

The cost efficiency test would use in this study based on a statistical model of bank production costs, and the banking data used in the model are from information banks supply in their reports. In this study, the fixed effect regression model (static model) is used to assess the effect of branch expansion cost efficiency of banks. Thus, equation can be represented by the following regression ((Coelli, 1995), p 328).

$\mathrm{TC}_{\mathrm{it}}=\beta_{0}+\beta_{1}$ price of labor $+\beta_{2}$ prices of capital $+\beta_{3}$ No branch $+\beta_{4}$ general inflation rate $+\beta 5 \operatorname{lnCAR}$ $+\beta_{6}$ liquidity $+\beta_{7}$ Total loan $+\beta_{8}$ prices of deposit $+\beta_{9}$ securties $+\beta_{10}$ market share +

$\beta_{11}$ managementperformances $+\beta_{12}$ real GDP growth

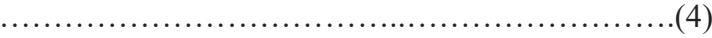

Where;

$\beta_{0}, \beta_{1}, \beta_{2}, \beta_{3}, \beta_{4}, \beta_{5}, \beta_{6}, \ldots . \beta_{12}=$ Coefficients of the independent variables

$\mathrm{i}=$ represents the individual bank and $\mathrm{t}=$ denotes time,

TCit $=$ dependent variable,

Xit = explanatory variables,

$\eta \mathrm{i}=$ unobserved individual effect (such as managerial ability, strategy or historical factors),

vit $=$ error term,

The study would apply frontier efficiency formula developed by Aigner, Lovell, \& Schmidt (1977) which is a function of input and output as follow:

$$
C E i t=\frac{f(W 1, W 2, W 3, W 4, Y 1, Y 2, Y 3, ; B) \exp (V i t)}{f(w 1, w 2, w 3, w 4, y 1, y 2, y 3 ; B) \exp (V i t+U i t)}=\exp (U i t)
$$

The value of $U_{i t}$ cannot be observed directly from the above equation; only the composite error term $\varepsilon i t=$ $\mathrm{V}_{\mathrm{it}}+\mathrm{U}_{\mathrm{it}}$ can be observed. A solution to this problem is obtained by using the distribution of the inefficiency term condition on the estimation of the composite error term. For the half normal case, Battese and Coelli (1995) proposed the appropriate point estimator for the cost efficiency, which involves the conditional expectation of $\exp (-\mathrm{Uit})$ given the entire error term. 


\subsubsection{Variable Construction and Description}

Through carefully examining the literatures, the researcher decided to follow or adopt the intermediation approach, commonly used by many authors. Researcher use the intermediation approach to measuring costs of a bank because a competitive and efficient institution would minimize the total operating and interest costs for any given output. Total cost is, therefore, the sum of interest expenses and general operating expenses. However, bank dividend payments are excluded from the measure of total cost, so the return to bank equity is not included in the measure of total cost.

Table 0:1 summery of operational definition prices of the variables inputs and outputs computed as follows

\begin{tabular}{|c|c|c|c|}
\hline .Variable & Variable name & Definition & Variable Sources \\
\hline TC & $\begin{array}{l}\text { Total } \\
\text { Costs }\end{array}$ & $\begin{array}{l}\text { Personnel Expenses }+ \text { Interest } \\
\text { Expenses }+ \text { Operating expenses }\end{array}$ & \\
\hline \multicolumn{4}{|l|}{ Inputs Prices } \\
\hline W1 & price of labor & $\begin{array}{l}\text { Proportion of all personnel } \\
\text { expenses to total assets. }\end{array}$ & $\begin{array}{l}\text { (M.Ariff, } \\
\text { 2011) }\end{array}$ \\
\hline W2 & prices of & $\begin{array}{l}\text { proportion of all non-personal } \\
\text { expenses Over fixed assets }\end{array}$ & $\begin{array}{l}\text { (M.Ariff, } \\
\text { 2011) }\end{array}$ \\
\hline W3 & $\begin{array}{l}\text { Number of } \\
\text { branch }\end{array}$ & $\begin{array}{l}\text { Proportion of Branches } \\
\text { operating expenses to total } \\
\text { branch. }\end{array}$ & bank scope \\
\hline W4 & prices of deposit & $\begin{array}{l}\text { an interest expense over total } \\
\text { deposits }\end{array}$ & \\
\hline \multicolumn{4}{|l|}{ output } \\
\hline Y1 & Total loan & $\begin{array}{l}\text { Represents the net loans, } \\
\text { overdrafts and interbank loans } \\
\text { less provision for doubtful loans }\end{array}$ & (M.Ariff, 2011) \\
\hline Y2 & Total securities' & $\begin{array}{l}\text { Represents the investments in } \\
\text { government securities }\end{array}$ & (HAILU, 2014) \\
\hline \multicolumn{4}{|l|}{ Control variable } \\
\hline Lnliqudityrisk & Liqudity risk & $\begin{array}{l}\text { Logarithm proportion of total } \\
\text { deposits to gross loans. }\end{array}$ & \\
\hline lnmagtperfo & $\begin{array}{l}\text { Management } \\
\text { performances }\end{array}$ & $\begin{array}{l}\text { Proportion of earning income to } \\
\text { total asset }\end{array}$ & $\begin{array}{l}\text { (Mohammed } \\
\text { Rahman , Badar } \\
\text { Ashraf } \\
\text { Changjun Zheng } \\
\text { and Munni Begu, } \\
\text { 2017) }\end{array}$ \\
\hline Marketshare & Market share & $\begin{array}{l}\text { Proportion of a fiscal year } \\
\text { deposit to total deposit sampled } \\
\text { banks of the year }\end{array}$ & $\begin{array}{l}\text { (Raphael G. , } \\
\text { 2013) }\end{array}$ \\
\hline $\operatorname{lnCAR}$ & $\begin{array}{l}\text { capital } \\
\text { adequacy }\end{array}$ & Capital asset ratio & \\
\hline \multicolumn{4}{|l|}{ Macroeconomicvariables } \\
\hline lnGinflation & $\begin{array}{l}\text { General } \\
\text { inflation }\end{array}$ & $\begin{array}{l}\text { Average food and non-food } \\
\text { inflation }\end{array}$ & (Alemu, 2015) \\
\hline lnrealGDP & RealGDPgrowth & Overall economic conditions & (Alemu, 2015) \\
\hline
\end{tabular}

Sources: Author formulation

Above mentioned method for estimating input prices was proposed by Coelli et al. (2005) and(Beletew, 2016). The inflation and real GDP growth rates are commonly used to control for the macroeconomic conditions as same as the following researchers (Alemu, 2015,p 46-50).

\section{Results and Discussion}

\section{Chapter 16 4.1. Descriptive Analyses}

Prior conducting any analysis, the panel data set was checked whether it is balanced or unbalanced using the stata command xtset bank year and showed that the panel data set is strongly balanced ${ }^{1}$ data. Then this section 
presents the Summary Statistics of dependent, explanatory variables and correlation analysis used in this study.

\section{Chapter 17 4.2.1. Summary Statistics}

It shows the summary descriptive results for all the variables used in the study such as mean, maximum, minimum, standard deviation, and number of observation. As atable4.1presented the summary statistics of four input variables (labor price, capital prices, prices deposit and prices of new branch expansion); and two output variables (prices of loan and security prices), environmental or macro-economic variablesand other control or bank specific variables that determines cost efficiency of fourteen Ethiopian commercial banks. Thereby, summarizeaverages, standard deviations, as well as the minimum and maximum values of basic and bank specific variables of commercial banks held within the sample study period.

Table 0:1 Descriptive Statistics for selected variables

\begin{tabular}{|l|l|l|l|l|l|}
\hline Variable & Obs & Mean & Std.Dev. & Min & Max \\
\hline TC & 126 & 1465.123 & 2472.132 & 499 & 19011.4 \\
\hline w1 & 126 & .067 & .169 & .005 & 1.784 \\
\hline lnW2 & 126 & .031 & .038 & .1 & .171 \\
\hline w3 & 126 & 1.225 & 1.447 & .022 & 8.5 \\
\hline w4 & 126 & .105 & .257 & .013 & 2.404 \\
\hline lny1 & 126 & 2.737 & .591 & 1.531 & 4.428 \\
\hline lny2 & 126 & 2.161 & .524 & .477 & 3.41 \\
\hline Man.tperfo & 126 & 1.053 & .153 & .927 & 2.353 \\
\hline lnGinflation & 126 & 1 & .087 & .857 & 1.146 \\
\hline realGDPgth & 126 & 6.633 & 2.61 & 3.4 & 12.4 \\
\hline lnCAR & 126 & -.861 & .168 & -1.414 & -.074 \\
\hline
\end{tabular}

Source: owner Computation from Annual Report of National Bank of Ethiopia, 2019

Table 4.1indicated that the annual total cost of the Ethiopian commercial banks attained, on average, 1,465.12 million ETB ${ }^{2}$ over the last nine years with maximum of 19,011.4million ETB and minimum of 499 million ETB. On the other hand, the standard deviation statistics for total cost was also 2,472.132million ETB which indicated that the cost variation between the selected banks was very high too.

Regarding the explanatory variables of the model there are some interesting statistics that have to be mentioned. On average, the labor price of Ethiopia commercial banks for the last nine consecutive years was approximately equals $6.7 \%$ with a maximum of $178.4 \%$ and minimum $0.5 \%$. The standard deviation statistics for labor prices would be $16.9 \%$ that reveals high variation in the labor price Ethiopian commercial banks. A possible explanation can be the existence of high salary variation on employee salary fee,training and motivating staffamong banks. In the same fashion the standard deviation statistics for branch expansion prices was also (144.7\%) which shows the existence of very high variation of branch expansion between the selected Ethiopian Commercial banks. This would be due to the fact thatsome commercial banks made few branch expansions and installation cost while others opened manybranches which lead tovery high variationcost associated withbranch expansion.

\section{Chapter 18 4.2.2Correlation Analysis}

Correlation is a way to index the degree to which two or more variables are associated with or related to each other (Brooks, 2008). The most widely used bi-variant correlation statistics is the Pearson product-movement coefficient, commonly called the Pearson correlation which was used in this study. Appendix 2 showsthe correlation of dependent and independent variables usedin thisresearch. The resultof this study revealsthatprices of labor, branch running, prices of deposit, loan output, securities output, liquidity risk,market share, and general inflation have positive association with total cost of commercial bank. This indicates that in commercial banks of Ethiopia the above listedvariables increase lead to increase in total cost to the banks. On the other hand prices of capital, management performances, real GDP growth and capital adequacy were found to be negativelycorrelated withtotal cost of Ethiopian commercial banks.

\subsection{Econometric Analysis}

The researcher conducted diagnostic tests to guard against the possibility of obtaining and interpreting spurious regression results. The results of the tests are presented in the following sections.

\section{Chapter 19 4.3.1Multicollinearity}

Before conducting the regression, it is pertinent to test Multicollinearity. Multicollinearity is the situation when some or all of the explanatory variables having a high degree of relation with each other and making it difficult to tell which of them is influencing the dependent variable (Gujarati, (2004). It is observed from appendix 1 and appendix 2, the result of the correlation matrix lays between the ranges of -0.06 and 0.79 . The higher the

\footnotetext{
${ }^{2}$ Ethiopian Currency Birr
} 
correlation between the predictor variables the higher the Multicollinearity. Specifically, the correlation above 0.8 considered as Multicollinearity and the above correlation among the variables is below 0.8 . Thus, our panel data are free from Multicollinearity problem as Variance inflation factor test show below.

Table 0.2: Variance InflationFactor

\begin{tabular}{|l|l|l|}
\hline Variable & VIF & $\mathbf{1}$ /VIF \\
\hline Markesthare & 9.906 & .063 \\
\hline lny3 & 8.173 & .109 \\
\hline lnW2 & 5.158 & .194 \\
\hline Magtperfo & 5.028 & .199 \\
\hline w1 & 4.114 & .243 \\
\hline Y1 & 4.095 & .244 \\
\hline lnw4 & 2.864 & .349 \\
\hline Lnforeighate & 2.836 & .353 \\
\hline Firmferfo & 2.823 & .354 \\
\hline lny2 & 2.208 & .453 \\
\hline lnw3 & 1.979 & .505 \\
\hline Liquditrisk & 1.865 & .536 \\
\hline lnGinflation & 1.449 & .69 \\
\hline realGDPgth & 1.26 & .793 \\
\hline Mean VIF & 4.34 &. \\
\hline
\end{tabular}

Sources: author own calculation stata14

We can use the variance inflation factor (vif) command after the regression to check for Multicollinearity. As a rule of thumb, a variable whose VIF values are greater than 10 may merit further investigation. Thus, the meanVIFwas4.34which indicate that there is no problem of Multicollinearity among the independent variables.

Chapter 20 4.3.2 Heteroscedasticity Test

The heteroscedasticity problems arise when the variance of the error term is not constant. If the errors do not have a constant variance, there would be heteroscedastic problem. As noted in Gujarati, (2004) the variance of the errors is constant, this is known as the assumption of homoscedacticity. Thereby, the researcher study would be employed the popular white test to detect heteroscedasticity. This test involves testing the null hypothesis that the variance of the errors is constant (homoscedacticity) or no heteroscedasticityagainst the alternative that the errors do not have a constant variance.

Table 0.3: Test for Heteroscedasticity

asdocxttest3

Modified Wald test for group wise heteroskedasticity

in fixed effect regression model

H0: $\operatorname{sigma}(i)^{\wedge} 2=\operatorname{sigma}^{\wedge} 2$ for all

chi2 $(14)=1631.53$

Prob $>$ chi2 $=0.0000$

Sources: author own calculation stata14

So the above result, researcher reject the null and conclude heteroskedasticity existed. Then the study applied robust regression to mitigate the problem of heteroskedasticity.

\section{Chapter 21 4.3.3 TEST FOR AUTOCORRELATION}

This is an assumption that the errors term in one-time period is correlated with the error term in any other time period. The study employed the popular Woodridge test for autocorrelation to detect the existence of serial correlation. Accordingly, the test statistics fails to reject the null hypothesis which says there is no serial autocorrelation. This implies that our model doesnot have the problem of serial autocorrelation.

Wooldridge test for autocorrelation in panel data

H0: no first order autocorrelation

$\mathrm{F}(1,13)=2.559$

Prob $>\mathrm{F}=0.1337$ 


\section{Chapter 22 4.3.4. Normality Test}

The other tests were carried out on the model which includes test of Normality. In order to conduct the normality assumption required a single or joint hypothesis tests about the model parameters. The popular Bera-Jarque test would be employed to check normality. According to (Gujarati, 2004,p 476)a normal distribution is defined to have a coefficient of kurtosis of 3 . In the same token, if the residuals are normally distributed, theBera-Jarque statistic would be significant at 5\% significant level. So that, thenull hypothesis is that the distribution of the residuals is normal. As shown in figure 4.1 below, the graphis bell-shaped and with $5 \%$ significance level, we failed to reject the null hypothesis. Therefore, the residuals are normally distributed in this study and there is no the problem of normality in the models. The kernel value 0.023 is less than $5 \%$ level of significance means the residual is normally distributed.

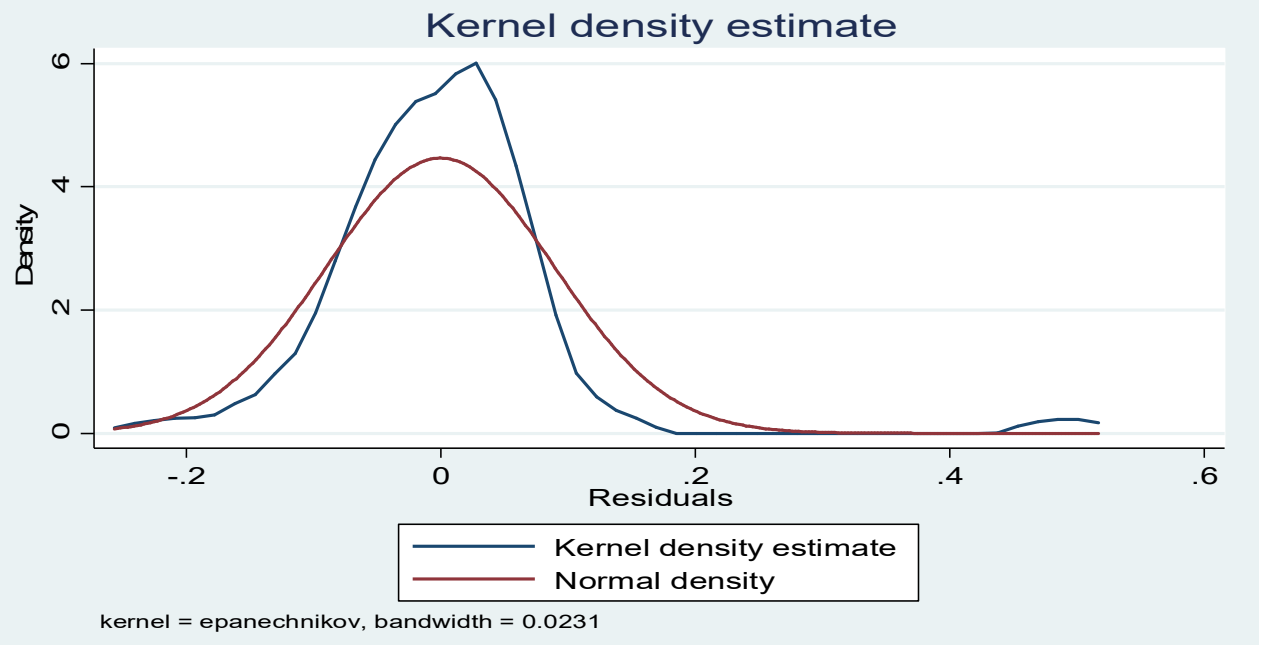

Figure 0:1 Normality test for residuals

Sources: author own calculation stata14

\section{Chapter 23 4.3.5. Model Selection Test: Random Model VersusFixed Effect Model}

Panel modeling enables to identify a common group of characteristics whilst, at the same time, considering the heterogeneity that is present among individual units(Baltagi, 2005). Prior to conducting the panel regression analysis, it is pertinent to selected between fixed or random effect models. To this effect, the Hausman test was performed to select the appropriate model between fixed and random model. The null hypothesis is that the preferred model is random effects and the alternative hypothesis states that the fixed effects are preferred. The result of the Hausman test is presented in Table 4.4., accordingly, the Hausman specification test fails to accept the null hypothesis which says random effect model is appropriate and accepted the alternative hypothesis which says fixed effect is appropriate at 5\% significance level. For further see regression result from appendix 4.

Table 4.4: Hausman Specification Test

\begin{tabular}{|l|l|}
\hline & Coef. \\
\hline Chi-square test value & 22.741 \\
\hline P-value & 0.03 \\
\hline
\end{tabular}

Sources: Author own stata14 calculation

Chapter 24 4.4 Estimation of Stochastic Cost FrontierAnalysisis

In order to estimate cost stochastic frontier coefficient's function and efficiency model the researcher used method of maximum likelihood function incorporated into Stata14.Then translog function is considered to be a suitable frontier estimation technique as according to Battese and Coelli (1995). Given that it is assumed that the cost function must be linearly homogenous in input prices, the assumption of homogeneity of degree one in input prices is introduced in the model. This is derived from the normalization of the total costs and input prices by the input price of capitals, i.e. w2, before the log transformation is effected on the model. According to Berger and Mester (1997) transformation is used to solve the problem of heteroskedasticity. According this test, the researchers check whether the cost function is stochastic function form or standard average response function form. As shown in appendix 5 the Parameter $\gamma$ (gamma) indicates the relevance of stochastic frontier model specification. It measures the variation between observed cost $\mathrm{x}$-inefficiency and the best practice on the frontier. If the value of gamma close to zero, all banks in the sample produces their output with the available inputs in the same way. That is, there is no inefficiency operation practice among the banks. Whereas, if the value is different from zero, there is an inefficient operation among the banks. So that, the reject of the null hypothesis $\gamma=0$, 
means that that the $\mathrm{x}$-inefficiency $(\mu \mathrm{i})$ be exist the model and there is difference in operational practice among banks. The shares of inefficiency from the total variance of cost function were about $65.9 \%$. This suggests that the variable error term or $(\mu+v)$ is explained much more by the variance of the component of $x$-inefficiency $(\mu \mathrm{i})$ than by that of the random error term $\mathrm{V}$. This reveals that the variation between actual value and the best practice on the frontier is due to $\mathrm{x}$-inefficiency. These ensure stochastic frontier model as appropriate to represent the data to measure the cost efficiency of commercial banks in Ethiopia.

Moreover, to test of time varying inefficiency model, the researcher used null hypothesis (H0) in this study is the inefficiency level of Ethiopian commercial banks time invariant (constant). This happens when Ho: $\eta=0$, this means no change in the $\mathrm{x}$-inefficiency effects over time, given the specification of the time varying $\mathrm{x}$ inefficiency model. On the other hand, the alternative hypothesis is the inefficiency effects vary overtime, this occurs when $H: \eta \neq 0$, either positive or negative value. The positive value indicates the inefficiency effects decrease from time to time; whereas the negative value indicates that the inefficiency effects increase from time to time. So when we see the outcome in appendix 5 too, the value is negative for the cost function (3.88). Therefore, we reject the null hypothesis and accept the alternative hypothesis at 5\% significant level. So that, the inefficiency effects has increasedfrom time to time in the sample period as fig 4.3 shows cost efficiency score of Ethiopian commercial banks.

On the other hand empirical results of the cost frontier estimation assumption about the distribution of the error term were also tried. Specifically, SFA were estimated but results were unreliable due to model instability arising from non-convergence even at a higher number of iterations. The researcher had attempted to test the $\mathrm{x}-$ inefficiency distribution test that shows the null hypothesis Ho: $\eta=0$, which specifies the stochastic frontier $x$ inefficiency effects is half normal distribution with non-negative value and the alternative Hypothesis $\mathrm{H}: \eta \mathrm{i} \neq \mathrm{o}$, which specifies the $\mathrm{x}$-inefficiency distribution is truncated normal with negative value. Thereby as reveals from appendix 5, the value of $\eta$ for cost $x$-inefficiency is 0.13 . Even though these values are different from zero, they are insignificant t-test. Therefore, we accept the null hypothesis that state the inefficiency distribution for is half normal distribution.

Time-invariant inefficiency model

Table 0:4 Empirical results of the stochastic cost frontier model

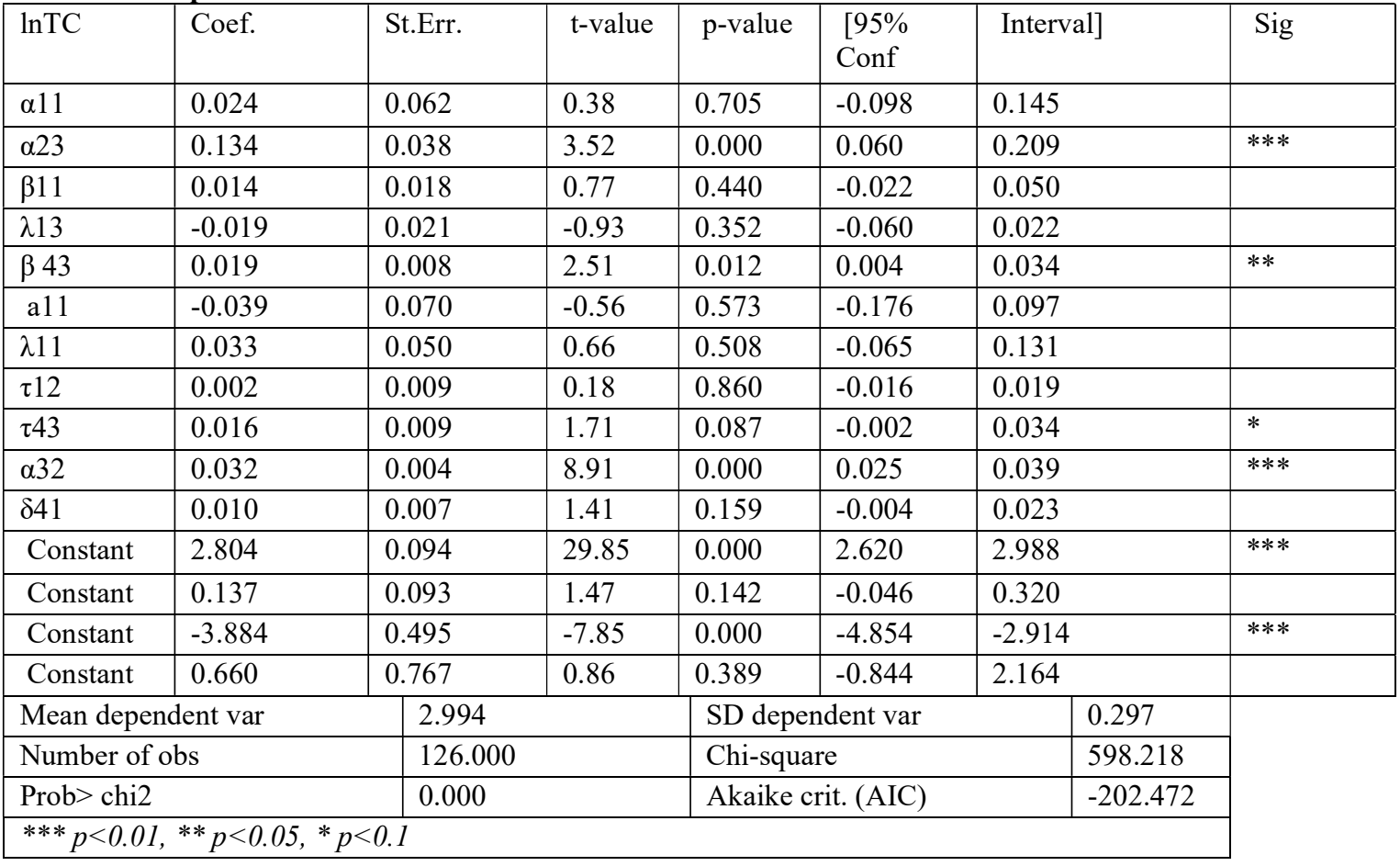

Source: own computation based on National Bank of Ethiopia (NBE) annually data

Log likelihood function $=116.2361$ and the notations $* * *, * * *$ shows level of significance at $1 \%, 5 \%$ and $10 \%$ respectively.

Given that the model is fairly complex due to the many interactions between output and input price variables of the Translog functional form, some of the estimated individual coefficients may not be directly interpreted. Moreover, according to (Joshua, $2011 \mathrm{p}, 42$ ) , the normalization of the variables allows that the estimated first-order parameters of the Translog function to be directly interpreted as the approximation of cost 
elasticity estimates. The main focuses of the analysis here is efficiency, So that, the conventional practice of individual parameters estimates are not discussed, because the Multicollinearity inherent in Trans log specification makes them difficult to interpret. But we can only note that the estimated coefficients are theoretically consistent and four out of the eleven parameters of the Tran slog cost function significant.

\section{Chapter 25 4.5 Branch Expansion Of Ethiopian Commercial Banks.}

Currently, the banking industry in Ethiopia is growing rapidly in terms of accessibility, asset development, capital accumulation, profitability, provision of loan and saving.Hence, theexpansion of banking service in the country plays a crucial role in the economy by creating opportunity for competitiveness. Rapid transaction enhances the money's speed of circulation in the market. It also helps control illegal transaction of money and whips it back into the formal one. In addition, it stimulates the economy through job creation via loan provision.Therefore, commercial banks should look for other new market opportunities. Because of the availability of infrastructural facilities helpful to run financial business, banks focus more on opening new branches all over the country. To accelerate the economic growth and development, Ethiopian banks has embarked reforms to towards branch expanding customer access, recruit new customer and encouraging competition.

In Ethiopian banking sectorstarting2010/11onwards to 2018/2019 fiscal year from the selected sample banks opened 4381new branches, raised the total number of branches to 5294 all over the country. The continuous expansions in branch network year after year imply the intensification of competition. As a result of the entry of private banks into the domestic banking business, lead to expand the number of branches, private banks have also followed an aggressive branch expansion strategy of their branches are concentrated where a great deal of business activities is executed.

Table 0:5 Average cost efficiency and branch expansion of Ethiopian banks

\begin{tabular}{|c|c|c|c|c|c|c|}
\hline No. & Bank name & $\begin{array}{l}\text { Avera } \\
\text { ge cost } \\
\text { eff. }\end{array}$ & $\begin{array}{l}\text { total branch } \\
\text { openedinnineyear }\end{array}$ & $\begin{array}{l}\text { Branch } \\
\text { growth rate }\end{array}$ & $\begin{array}{l}\text { Total branch } \\
\text { in a fiscal year } \\
2010 / 2011\end{array}$ & $\begin{array}{l}\text { Total branch in } \\
\text { a fiscal year } \\
2018 / 2019\end{array}$ \\
\hline 1 & Zemen bank & 0.962 & 44 & 5.2 & 3 & 47 \\
\hline 2 & Buna bank & 0.959 & 198 & 22.2 & 11 & 209 \\
\hline 3 & Lion i/al bank & 0.956 & 205 & 23.56 & 30 & 235 \\
\hline 4 & Oromia i/al bank & 0.953 & 241 & 23.56 & 36 & 277 \\
\hline 5 & Birhan i/al bank & 0.951 & 208 & 23.89 & 11 & 217 \\
\hline 6 & Abay bank & 0.948 & 192 & 22.22 & 8 & 200 \\
\hline 7 & Nib i/al bank & 0.937 & 229 & 27.78 & 51 & 280 \\
\hline 8 & Wegagen bank & 0.937 & 302 & 33.89 & 53 & 355 \\
\hline 9 & United bank & 0.921 & 244 & 27.22 & 50 & 294 \\
\hline 10 & Bank of Abyssinia & 0.914 & 296 & 33.89 & 57 & 353 \\
\hline 11 & $\begin{array}{l}\text { Cooperative bank } \\
\text { Oromia }\end{array}$ & 0.906 & 356 & 40.1 & 43 & 405 \\
\hline 12 & Dashen bank & 0.897 & 354 & 40 & 65 & 421 \\
\hline 13 & Awash bank & 0.894 & 353 & 44 & 70 & 423 \\
\hline 14 & $\begin{array}{l}\text { Commercial bank } \\
\text { Ethiopia. }\end{array}$ & 0.758 & 1102 & 132.4 & 417 & 1578 \\
\hline \multicolumn{2}{|c|}{ Total } & & 4324 & & 970 & 5,294 \\
\hline
\end{tabular}

Sources: Author own calculation and NBE report

Table 4.6 indicated that the almost all commercial banks of Ethiopia have been opened branches aggressively.Commercial Banks branch expansion is the principal interface between banks and their clients. The distribution of branches within and across outlying areas defines markets for financial services, because branches are where deposits are held and loans are arranged and enable banks to be profitable over time.

From bank industry especially the public bankCommercial Bank of Ethiopia (CBE) increasedits branch expansion from year to year; which opened 1192 branches in the study years. Moreover, commercial bank of Ethiopia(CBE) get lion share which had been opened more branches all over the country with eight (8) additional outside of the country in south Sudan in the last nine years. Perhaps the merging case Construction and Business Bank (CBB) in March 2016 with 120 branches might also contribute on CBE creating strong on its branch expansion, asset holding and number of employee after decision made 22 December 2015 by government of Ethiopia.Above all, CBE is aggressively expanding its branches across the country with the objective of increasing the saving habit of the society while being closer to the un-banked society. Obviously, Ethiopia's banking system is dominated by government-owned banks. It played a great role in developing the Ethiopian economy through the activation of financial system, providing funds for mega projects in infrastructure and 
social services and inventing new services and products to move surpluses to sectors which have deficits.

In other hand the private bank sectors even though low in comparison with CBE,banks like Awash international bank,Cooperative bank Oromia, Dashenbank and Abssiniya bank and had also more branches opened better than the remain private banks inbranch growth rate $44 \%, 40.1 \%, 40 \%$ and $33.89 \%$ respectively in the study years. In addition to that Wegagenbank,United bank and Nib international banks also made not ignorable branch expanded in the study period. In a surprising way the youngest banks which had been established between 2006 and 2010 fiscal year banks namely, Lion international bank, Oromia international bank, Buna bank, Birhan international and Abay banks expended in aggressive way of open their branches all over the country.

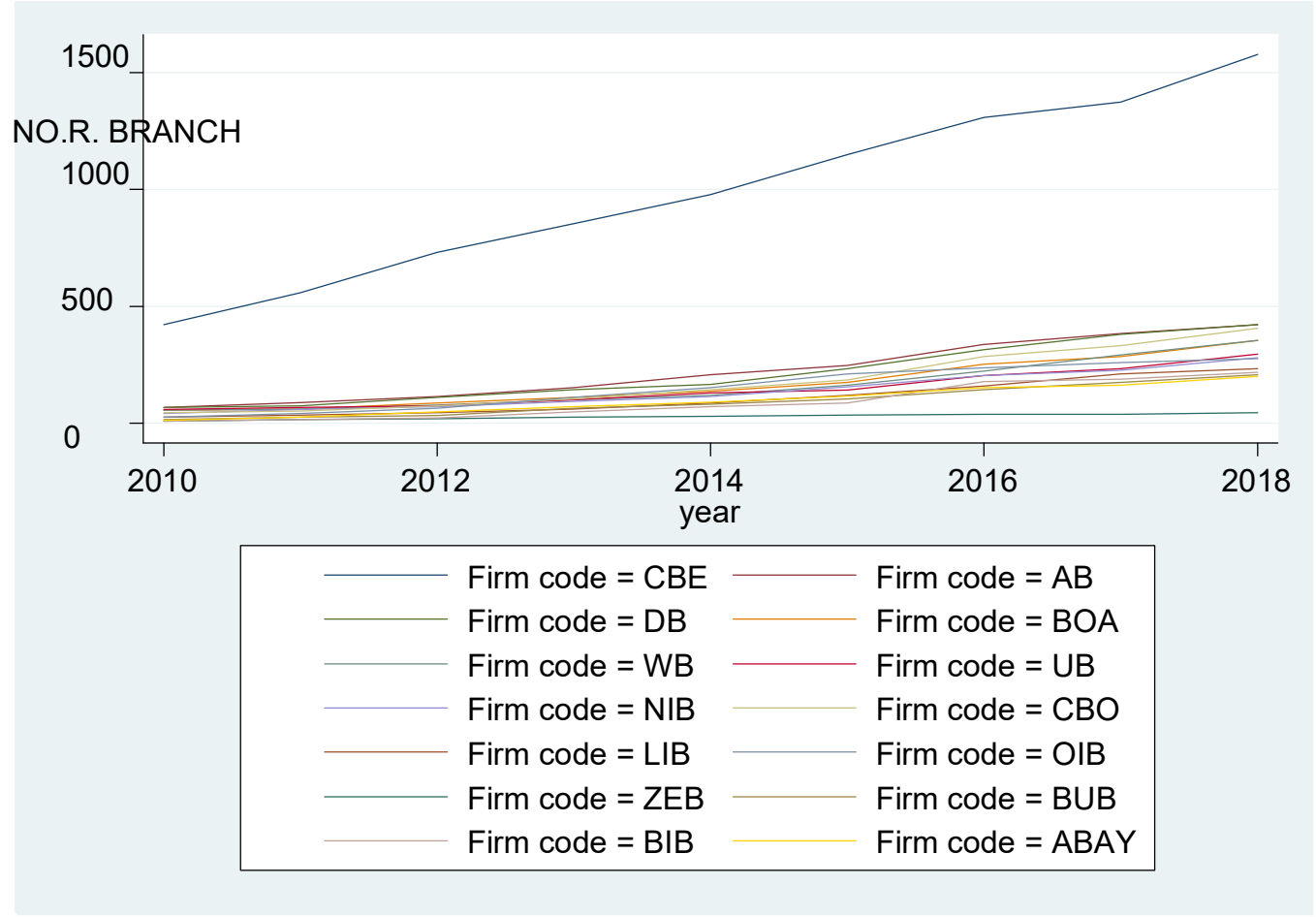

Figure 0:2 branch expansion profile commercial banks of Ethiopia

Source: Author's own calculations

However, Zemen bank the youngest private bank would be least number of branch opened all over the country. A possible reasonable explanation for the case is justZemenbank focus on corporate, high net worth individuals, and institutional clients offer customer to runinitial deposit account was 25,000 and 5,000 birr from the two previous years onwards could lead as constraint to expand branch. Moreover, their choices of locations in which to invest in new branches are surely based on expected returns on the spot. Alternatively, in a world of imperfect information, the bank also filter decisions by other banks for clues about where future prospects. In surprisingly, the youngest banks in which established from millennium of Ethiopia onwards did not open more branch but they were better in cost efficiency as depicted belowFigure 4.3. So the researcher found that as branch expansion increasing aggressively, their cost efficiency of commercial banks of Ethiopia decline at increasing rate as depicted the figure below(4.3).

\subsection{Determinants of Ethiopian Commercial Bank Cost Efficiency}

The study used panel data econometric investigation on bank specific and macroeconomics variables to assess the effect of Bank branch expansion on the cost efficiency of commercial banks of Ethiopia.Overall, the regression results show that relatively low average cost efficiency scores during the study period. This suggests that Ethiopian banks are operating far from the cost efficiency frontier. This also implies that banks can obtain bigger cost practices in input-usage and inefficiencies. Thus, Ethiopian banks explained inadequate control of their operating expenses and therefore less focus on cost management In other words, underutilization of input resources by Ethiopian commercial banks could, in part, be attributed to banks expansion generating higher amount of costs which are yet to produce returns. 


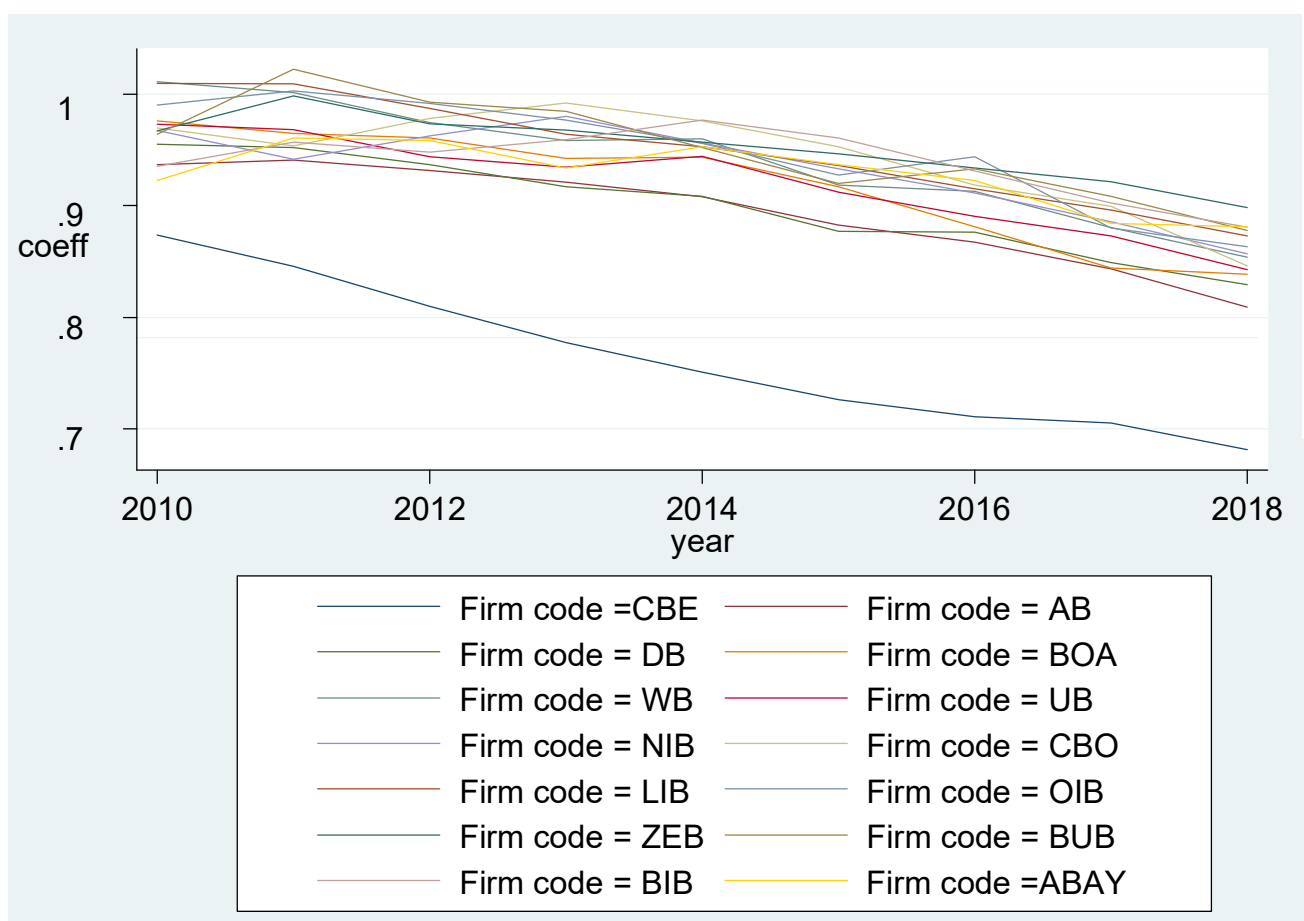

Figure 0:3 Cost efficiency of commercial banks of Ethiopia

Source: Author's own calculations

The cost of using, input-output is high and access usage. Similar empirical evidence in Ghana banks confirm the high cost of input price and high loans contributing output to high operating costs might explain the low level of efficiency of the banks(Adjei-Frimpong, 2013 ,p32).

Generally is shown by the trend in the cost efficiency estimates depicted by figure 4.3 illustrates efficiency scores for the annually observations; for each commercial banks sustained downward trend in cost efficiency, depicting increase in inefficiency over the sample period. However the researcher found that almost all the private commercial banks were more efficient than their public counterparts in terms of CE in almost all the sample years.

According to the regression results, bank cost efficiency as the dependent variable depicted in the Table4.7 below shows thatreal GDP capita growth rate, prices of capital (W2), management performances and capital adequacy ratiowere positive significant variable on cost efficiency of commercial banks. That generally consistent with our expectations significant at except real GDP capita growth rate at $10 \%$ significance levelremain variables are statistically significance at 5\% level of significance. While market share, labor prices(W1),new branch installing cost (W3),prices of deposit (W4),total loan (y1),securities (y2),liquidity risk and general inflation were negatively significant influencing the cost efficiency of Ethiopian commercial banks. 
Table 0.6 Regression Results of Ethiopian Commercial Bank Cost Efficiency

\begin{tabular}{|c|c|c|c|c|}
\hline VariablesCoeff & Coefficient & St.Err. & t-value & p-value \\
\hline $\ln w 1 * * *$ & -0.049 & 0.001 & -47.63 & 0.000 \\
\hline $\ln \mathrm{W} 2 * * *$ & 0.298 & 0.021 & 13.90 & 0.000 \\
\hline $\ln w 3 * * *$ & -0.007 & 0.000 & -13.79 & 0.000 \\
\hline $\ln w 4 * * *$ & -0.012 & 0.001 & -19.93 & 0.000 \\
\hline $\operatorname{lny} 1 * * *$ & -0.137 & 0.002 & -71.63 & 0.000 \\
\hline $\ln y 2 * * *$ & -0.008 & 0.001 & -7.96 & 0.000 \\
\hline Lnliquditrisk $* * *$ & -0.016 & 0.002 & -10.39 & 0.000 \\
\hline Lnmagtperfo $* * *$ & 0.003 & 0.001 & 5.01 & 0.000 \\
\hline Marketshare*** & -0.129 & 0.033 & -3.88 & 0.000 \\
\hline ginflation $* * *$ & -0.001 & 0.000 & -3.76 & 0.000 \\
\hline lnrealGDPgth* & 0.004 & 0.002 & 1.67 & 0.095 \\
\hline $\operatorname{lnCAR} * * *$ & 0.069 & 0.004 & 16.31 & 0.000 \\
\hline Constant & 1.185 & 0.006 & 199.07 & 0.000 \\
\hline Mean dependent var & 0.920 & & & \\
\hline Overall r-squared & 0.996 & & & \\
\hline Chi-square & 29471.969 & & & \\
\hline R-squared within & 0.993 & & & \\
\hline
\end{tabular}

Source: Author's own calculations

According to the regression results, labor prices (W1) was generally consistent with our expectations significant at 5\% level of significance. Labor prices (W1) -0.049 coefficients suggests that without any control and environmental variables $1 \%$ increase in labor prices would decrease cost efficiency by $4.9 \%$. This shows negative statistically significant up on cost efficiency and positive associated with cost. This implies that holding other variables constant increase $1 \%$ in price of labor leads to an increase in the total cost of banks by $18 \%$. This is perhaps due to the fact that a high level of spending on labor might lead to high cost bank or cost inefficiency. The analysis has found out that average amount of expenses on staff salary is the price paid or idle staff existed in the bank. Therefore, previous study indicate(Musonda, 2008) input price for labor (approximate wage rate) is positive and significant, implying that increases in banks labor costs are directly reflected in higher total operating expenses. (Tesfaye \& Abdurezak , 2017)states that management's capacity to control the level of labor expenses will be one of the determinant factors besides banks' capacity to build their liquidity through creating a reliable and cost effective deposit mixes.

On theother hand, the co-efficient of Prices of capital (w2), indicates that the non-interest Expenses including depreciation, amortization, promotion and others for fixed asset or proportion of all non-personal expenses Over fixed assets were proxy variable. It shows that Ethiopian commercial banks are cost efficient when they increase capital input. On average as of capital input increase by $1 \%$ the cost efficiency of Ethiopian commercial banks increased by $29.8 \%$. This indication explained that commercial banks invest more, capital goods to promoting themselves services delivery like latest e-bank system, computer machine, generator and other facility of fixed asset lead to build trust in the banking. This implies that holding other variables constant increase $1 \%$ in price of capital input leads to decrease in the total cost of banks by $89.4 \%$.In short the price of capital has a negative effect on the total cost. The researcher founding was consistent with previous study indicate(Sanderson A, Alex B\& Pierre Le R , 2019) and(Musonda, 2008)for capital input costs had positive and significant on the cost efficiency parameter estimated.

The branch expansionvariable (W3) that shows the proportion of Branches operating expenseson installing and running cost to total number of branches opened. According to the regression results $1 \%$ increase in branch installing and running cost will decrease cost efficiency by $3 \%$. This implies that holding other variables constant increase $1 \%$ in branch installing and running cost leads to an increase in the total cost of banks by $2.2 \%$. One explanation in this case is to get more profit, collect more deposit opening more branch and reach access to customer becoming fact more cost. Even, in recent year's dynamic bank completion to satisfy customer need providing and chosen to operate with a single branch model supported by multichannel banking system increase which leads rise cost. The another plausible explanation due to sky-rocketing office rent, cost of stationary, generator andpatrolfuel,IT installation, Telecommunication network fee, insurances would be cost. The researcher third explanation for the case is that, the order of national bank of Ethiopia to increase their branch size by $25 \%$ per annum and the aggressively branch opening lead them cost inefficient. So that government stance only towards creating access to finance to the poor through establishing bank premises all over the country. Therefore, this is done not only due to the banks' choice of branch as a growth driver but a strategy need to be pursued to fulfill regulatory requirement. In addition, the choice of branch opening is subjected to approval from the regulatory side and is not under the discretion of the Banks. Similarly with early researches 
this branch expansion of banks tends to reduce the cost efficiency level associated with raising overhead expenses (LELISSA, 2017)and (Joshua, 2011 p,42)). In the same fashion previous researcher, (Mesfin, 2009)found that due to branch expansion that causes banks to incur more cost for rent, administration and other contingent costs and management attention may divert from cost minimization to focus on to other routine administration activities. This increases cost inefficiency because of the direct relationship of cost and cost inefficiency.(Musonda, 2008)banks expand branches to get closer to customers. However, this also leads to an increase in operating costs of bank branches. Branch expansion activity tends to weaken banks efficient performance by raising overhead expenses.

A Price of deposit (w4) shows the Proportion of an interest expense over total deposits. This implies that holding other variables constant increase $1 \%$ in deposit prices leads to an increase in the total cost of banks by $3.9 \%$. The study ascertains that banks aggressive branch opening that has positive correlation with prices of deposit with respect to widening customer base and increased financial inclusion through creating accessibilities to the unbanked rural and urban areas. Expanding the banking system will create greater savings opportunities that will in turn boost funding via savings and incurred costs in the same fashion. As a result , the study exhibited on average other things remain constant $1 \%$ increase in deposit prices lead to decrease cost efficiency by $1.2 \%$ unit in Ethiopian commercial banks. The other explanation can also NBE directive NO.SBB/45/2008 statutory reserve requirement obliges banks to hold a proportion of their deposit balance (which is $15 \%$ of the total deposit) with national bank of Ethiopia. This reserve requirement is high relative to other country. The fund reserve in the national bank of Ethiopia is no earned interest, so it is a cost for the banks or a tax on financial intermediation. Because the higher the reserve ratio, the lower the available deposit fund to revenue earning activities lead cost inefficient.

Total loan (y1) represents the net loans, overdrafts and interbank loans less provision for doubtful loans. Total loan (y1) coefficient suggests that $1 \%$ increase in loan output will decrease total cost efficiency by $13.7 \%$, and it show a negative relationship. This implies that holding other variables constant decrease $1 \%$ in branch total loan providing leads to an increase in the total cost of banks by $47.7 \%$. The coefficient indicates that the Ethiopian commercial banks provided loan with high lending interest rate but non-performing loans and inadequate credit monitoring lead them cost inefficient. This result supports the finding of(K. Adjei-Frimpong et al 2014), who find loan loss provision to be negatively related to bank cost efficiency in Ghana's banking industry reflects the higher cost of operation mainly due to inadequate credit monitoring and inefficient control of operating expenses particularly high staff cost and cost of funds, Yildirim\& Philippatos (2007) and Brissimis et al. (2008) and (Musonda, 2008) poor quality of credit increases the Zimbabwe banks cost lead cost inefficient.

Total securities (y2), represent investment securities (treasury bills, government bonds and other securities).Holding other variables constant increase $1 \%$ in total securities output leads to an increase in the total cost of banks by $2.4 \%$ have negative statistical significant on cost efficiency. The total securities coefficient suggests that $1 \%$ increase in securities output will decrease cost efficiency by $0.8 \%$, and it show a negative relationship. The bill purchase by commercial banks has likely adverse effect on their finical efficiency performances. The main explanation is, in Ethiopia bank sector the introduction of a significant policy change in the financial sector that occurred in March 2011, NBE issued a directive requiring all private commercial banks to hold $27 \%$ of new loan disbursements. This is basically with the intention to support the mega national development project, the Grand renaissance dam. The main complains with regard to such requirement from banks is related to the lower yield (3\%) from bills that doesn't even cover the minimum cost of fund required to be paid for saving and time deposit. This perhaps the researcher found that frustration for the commercial banks lead them cost inefficient.However the NBE lifts bill purchase directive on came into effective November 20 , 2019 that was yearlong mandatory requirement imposed on private banks to purchase bonds from Development Bank of Ethiopia (DBE).

The liquidity risk variable represents the logarithmic proportion of total deposit to gross loan that refers the ability of financial firm to maintain equilibrium between the financial inflow and outflow of cash.Estimating liquidity risk requires knowledge of the turnover rates of the bank's sources of funds, particularly deposit turnover. Concerning the liquidity risk, the regression results of this study implies that the relation between liquidity risk and cost efficiency is negative and significant at $1 \%$ significance level ( $\mathrm{p}$-value $=0.00$ ). This reveals that holding other variables constant increase $1 \%$ in branch liquidity risk leads to an increase in the total cost of banks by $4.7 \%$.The result indicates that the liquidity variable has a significantly negative influence on bank cost efficiency. This implies that high figures for this variable low bank cost efficiency. This finding explains that in commercial banks increase liquidity mean idle liquid cash which is not channelized to loan. So if commercial banks no disbursed in terms of loan and return principal plus interest lead inefficiency. The result is consistent with the findings of Molyneuxet al., (1992) and Guru et al. (1999) who concluded in their study that liquidity negatively correlates with cost efficiency.

According to the regression results depicted in the table4.7 Management performances means that Proportion of earning income to total asset that indicates the management of these banks towards cutting down 
on their operating costs although with increasing income revenue of the firm. It has a positive and significant at $5 \%$ level effect on bank cost efficiency. On average $1 \%$ improve management performances lead to $0.3 \%$ increase cost efficiency scores. This implies that holding other variables constant increase 1\% in management performances leads to decrease in the total cost of banks by $0.6 \%$. This founding can be attributed to sound management strategies aimed at cutting down on operation costs. From possible explanation bank management performancescan be explained by the various strategies adopted by the managers of these banks to cut on costs.From various strategies of the bank management, expense control mechanism, deposit mobilization strategy-banking multichannel accesses ability, recruitment capital goods and others were reduces cost incurred by the bank enable cost efficient.Bank's performance management measurement and assessment are one of the most important agendas in today's business world. Failure to do some satisfactory performance may damage the bank's reputation, leading to customer defections and breakdowns with other key stakeholders, such as deterioration or loss of investor confidence in management. Thus, banks not only need to be profitable, but also efficient; otherwise, it may create instability and obstacle in the process of development in any economy .The bank management was able to align the company's resource such as human resource, capital technology and financial in to effective inputs and outputs. In other words, on average, management of the banks could have produced the more amounts of outputs with fewer percent input resources. There is one indication point no more waste of valuable resources in the Ethiopia banking system over the period under study.

On the other hand, Market share represents the in this paper (in terms of deposit) is considered as a proxy of bank size. Since the variable Market share is highly correlated to bank size (log of total asset). This was statistically significant and negatively related with cost efficiency of commercial banks of Ethiopia at $1 \%$ significance level. That is, commercial banks with relatively large size tend to be less cost efficient than others. The study found out that $1 \%$ increment on bank market share yields $12.9 \%$ decrease cost efficiency. This implies that holding other variables constant increase $1 \%$ in market share leads to an increase in the total cost of banks by $4.23 \%$. This perhaps explained in bank industry of Ethiopia as branch expanded far from head quarter; total asset rise and increase bank market share there would be less control over resources brings out inefficiency.

The general rate of inflation is considered as a viable measure of macroeconomic uncertainty and policy stance in any economy. It has in our case a negative and significant effect on bank cost efficiency. The coefficient -0.001 indicate that, the inflation affects the bank cost efficiency negatively. When inflation of the countries increases by 1 -unit, the other things remain constant the banks cost efficiency will decrease by $0.1 \%$ units. This implies that holding other variables constant increase $1 \%$ in general rate of inflation leads to an increase in the total cost of banks by $0.4 \%$. One possible explanation an increase in inflation rate leads to increase in bad debts which reduces bank cost efficiency due to the banks incur more costs in managing bad debts indicating a negative relationship between inflation rate and cost efficiency. Perhaps the second justification for the case is when general inflation levels increase economic agents convert their money holdings into assets to reduce of their purchasing power. Therefore, their demand for money increases and money held in bank accounts decline lead bank inefficient.

This is consistent with economic theory, as inflation rises households forego banking products. Households are expected to buy properties and other real assets to cushion themselves against loss in purchasing power of their monies. However, in many literatures the effect of inflation is not clearly defined but in this study the relationship between cost efficiency and inflation is negative.

On the other hand macro economy variable the real GDP growth rate has a positive and significant effect on bank cost efficiency. One possible explanation real GDP growth rate has a positive and statistically significant at 10 percent level effect on bank cost efficiency is that during higher economic growth increased demand for bank and banks lower their operating standards, such as way reduce their costs and thereby become more cost efficient. This reveals that holding other variables constant increase $1 \%$ in real GDP capital growth leads to decrease in the total cost of banks by $0.9 \%$.Economy growth could create a new and potential demand for financial services and it might reduce the default loan provision. This shows that the real GDP economic growth affects bank performances through increasing interest income, decreasing loan provision cost and operating cost that yields to increase the banks' cost efficiency. This finding is consistent with the studies of (Jimenez et al., 2009) and Maudos et al. (2002), where real GDP growth rate is positively related to bank cost efficiency, but opposite to the findings of Fries \&Taci (2005) and Chan \&Karim (2010) on the Middle Eastern or North African banks.

Finally from main determinates of bank cost efficiency, Capital adequacy ratio measures the amount of bank's capital which is related to the amount of is risk-weighted credit exposure. This shows that holding other variables constant increase $1 \%$ in Capital adequacy ratio leads to decrease in the total cost of banks by $26.9 \%$.Capital adequacy ratio is regulated in Basel regulation and banks must obligate that why it is an important factor that all banks must concern. Capital adequacy the coefficient of capital adequacy which is measured by the equity to asset ratio was positive and statistically significant at $1 \%$ significance level ( $\mathrm{p}$-value $=0.000)$. The positive coefficient for capital adequacy was in favor of the signaling or bankruptcy costs hypotheses and in 
opposite to the risk-return trade-off hypothesis. Moreover, the coefficient of the ratio of equity to asset which was relatively higher as compared to other variables shows that an increase in capital adequacy would result in increased cost efficiency. This is in line with the expectation as a bank with a sound capital position is able to pursue business opportunities more effectively and has more time and flexibility to deal with problems arising from unexpected losses, thus achieving increased bank cost efficiency.

\section{Conclusion}

Determinants were identified in to two main categories; the bank specific input-output variables determinants and macro-economic policy variables variable. The input-output prices determinants refer to the bank-specific determinants of efficiency. While, the other macro-economic determinant is variables that are not related to bank management but are related to the economic and legal environment that affects the operation and performance of the bank industry in country or global wide.

The result of the study indicates that the average cost efficiency of Ethiopian commercial banks is 0.92 over the period 2010/2011 up to2018/2019. Moreover, the study attested that state owned commercial banks with a cost efficiency score are less cost efficient than the private commercial banks. The results show that the banking sector in Ethiopian experiencing on average $8 \%$ percent level inefficiency score, implying that there are wastage in the banking sector. If this cost inefficiency is resolved, the commercial banks could pass on the reduced cost to their clients in the form of reduced interest rates as well as bank charges and fees.

Moreover, the study had explored results of the determinants of bank cost efficiency demonstrated that: Concerning the bank-specific characteristics:

$>$ Positive and statistically significant effect of the capital prices (w2), management performances, the real GDP capital growth and the capital adequacy ratio on cost efficiency were concluded based on researcher findings.

$>$ There was a negative and statistically significant relationship of the labor 1 prices(w1), branch running cost(w3), deposit prices (w4), total loan output(y1), security and investment(y2), liquidity risk , market share and general inflationon cost efficiency commercial banks.

$>$ The Ethiopian commercial banks expanded their service outlets (branches) throughout the country's territory; most of the branches were opened. This helped to mobilize their resources in the form of deposit, collection of loans and borrowing to different sector of the economy. However their cost efficiency would be decreased as they aggressively opened in the study years.

$>$ Private Banks management should take more consideration and feasibility study for opening new branches, especially branches to open outside Addis Ababa (the capital and business center of the country) because branches open on this city expected more efficient than other area of the country. The following factors should consider in opening any branches such as need of banking services in the area, selection of site and other relevant factors before opening new branch. Because branch expansion has an adverse effect on cost efficiency.

$>$ The bank managers had transformed the inputs like human resource, financial, technological, capital and deposits into effective inputs and profitable outputs relative to other private banks in Ethiopia Zemen bank was relatively best practiced terms of cost efficient and branch expansion in contrary to Commercial Bank of Ethiopia( CBE).

$>$ Despite the various challenges, banks preferred to go ahead aggressively expanded with its plan to open more branches to reach customers still.

\section{References}

a M.Y. Arafat et al. (2013,p 16). Banking efficiency and performance: a test of banking characteristics in an emerging market. J. Global Business Advancement, Vol. 6, No. 1, 2013, 16.

Aderaw Gashayie1, D. M. ( 2016 ). Development of Financial Sector in Ethiopia: Literature Review . Journal of Economics and Sustainable Development ISSN 2222-1700 (Paper) ISSN 2222-2855 (Vol.7, No.7), 17-18.

Adjei-Frimpong, K. (2013,p 83). Bank Efficiency and Bank Competition. Empirical Evidence from Ghana's Banking Industry, 32.

Admassu B, P. (Apr 2014,p 26). Banking Sector Reform in Ethiopia. International Journal of Business and Commerce Vol. 3, No.8: Apr 2014[25-38] (ISSN : 2225-2436), 26.

Adongo, J. C. (2005). Measuring the Alternative Profit X-efficiency of Namibia's Banking Sector. The Namibian Economic Policy Research Unit. Adongo, J., Christoph, S. and Elisa,H. (2005). Measuring the Alternative Profit X-efficiency of Namibia's Banking Sector. The Namibian Economic Policy Research Unit. (Research Report No. 36.

Alemu, S. (2015,p 46-50). DETERMINANTS OF COMMERCIAL BANKS PROFITABILITY: THE CASE OF ETHIOPIAN COMMERCIAL BANKS. unpaplished, 46-50.

Baltagi, B. H. (2005). Econometric Analysis of Panel Data 3rd edtion. John Wiley \& Sons Ltd, The Atrium, 
Southern Gate, Chichester, West Sussex PO19 8SQ, England.

Beletew, E. (2016). Determinants of Commercial Banks' Cost Efficiency in.

Berger, A. \& Humphrey, D. . (1997). Efficiency of Financial Institutions: International Survey and Directions for Future Research. European Journal of Operational Research 98, 175-212.

Berger, A. N. (?). The Effects of Geographic Expansion on Bank Efficiency. 9.

Coelli, G. E. (1995). A Model for Technical Inefficiency Effects in a Stochastic Frontier Production Function for Panel Dat.

Deribie, E. (2013). Expanding Branches of Commercial Bank of Ethiopia and the Position of Private Banks. Expanding Branches of Commercial Bank of Ethiopia and the Position of Private Banks ., 121.

Ecobank, R. N. (2013). Nbe \& Ecobank. 30.

Fanta, W. (2014,38). DETERMINANT ANALYSIS OF CUSTOMERS SWITCHING BEHAVIOUR IN PRIVATE COMMERCIAL BANKING SECTOR OF ETHIOPIA. unpublished, 38.

Farrell, M. (. (1957). The Measurement of Production Efficiency. The Measurement of Production Efficiency, Journal of Royal Statistical Society , 253-281.

Floros \&Georgia . (2008). ATM and banking efficiency: the case of Greece. Banks and Bank Systems, Volume 3 , Issue 4, 2008, 55-60.

Gezae, A. (2015,p4). Determinants of Banking Sector Development in Ethiopia . unpublished.

Hailing Zhao, Sangmok Kang. (2015,p 185). Cost Efficiency of Chinese Commercial Banks . International Journal of Finance and Accounting 2015, 4(3): 180-186 DOI: 10.5923/j.ijfa.20150403.0, 185.

HAILU, A. (2014). TECHNICAL EFFECIENCY OF COMMERCIAL BANKS OF ETHIOPIA.(IN THE CASE OF PRIVATE COMMERCIAL BANKS) . 16.

Hasan M, K. A. (2012). Hasan M, Kamil AA, Mustafa A, Baten : Measuring Domestic Bank Efficiency in Malaysia. Hasan MZ, Kamil AA, Mustafa A, Baten MA (2012) A Cobb Douglas Stochastic Frontier Model on Measuring Domestic Bank Efficiency in Malaysia. PLoS ONE 7(8): e42215.

https://en.wikipedia.org/wiki/Tigray_Region. (2019). https://en.wikipedia.org/wiki/Tigray_Region.

(n.d.). https://www.encyclopedia.com/places/africa/ethiopia-political-geography/tigray. 2019.

Joshua, K. (2011 p,42). DETERMINANTS OF COST EFFECIENCY LEVEL OF COMMERCIAL BANKS IN KENYA. 46.

K.Rama M. and Tekeste B.L. (2012). Cost Efficiency and Ownership Structure of Commercial Banks in Ethiopia. European Journal of Business and Management www.iiste.org ISSN 2222-1905 (Paper) ISSN 2222-2839 (Online) Vol 4, No.10, 2012, 44.

Kangethe, E. (2009,p10). RELATIONSHIP BETWEEN OPERATIONAL EFFICIENCY AND GROWTH OF COMMERCIAL BANKS IN KENYA, 8-10.

Khalil et al. (2014 ,p 111). Cost Efficiency of Pakistani Banking Sector. Vol.7, No.3 pp.110-126, 111.

KothariI, C. (2004). RESEARCH METHODOLOGY: methods and techniques. New Delhi: New age internationl.

KOZO Harimaya and Kazumine kondo. (2016). The Effects of Branch Expansion on Bank Efficiency: Evidence from Japanese Regional Banks. The Effects of Branch Expansion on Bank Efficiency: Evidence from Japanese Regional Banks, 8.

Leibenstein, H. (. (1966). Leibenstein, H. (1966). Allocative efficiency versus X-efficiency. American Economic Review Vol. 56, P392-415.

LELISSA, T. B. (2017). THE IMPACT OF INDUSTRY CONCENTRATION ON PERFORMANCE, EXPLORING A COMPREHENSIVE BANK PERFORMANCE MODEL: THE CASE OF THE ETHIOPIAN BANKING SECTOR .

Loretta J. Mester . (july 2003). APPLYING EFFICIENCY MEASUREMENT TECHNIQUES TO CENTRAL BANKs. WORKING PAPER NO. 03-13, 8.

M.Ariff, V. a. (2011). Efficiy measurment and determinants of Indonesan Banks efficincy.(2011).

Md. Hashibul H\& Mahmudul H. (2018,p217). Cost efficiency of banking sector of Bangladesh: evidence using the stochastic frontier analysis. Asian Journal of Empirical Research Volume 8, Issue 6 (2018): 208-224, 217.

Mesfin, S. (2009). Cost Efficiency and Profitability Analysis of Private Commercial Banks in Ethiopia. unpapulished, 67.

Mester, L. J. (2003). Workshop on Central Bank Efficiency Sveriges Riks bank Stockholm. Workshop on Central Bank Efficiency Sveriges Riks bank Stockholm.

Mohammed Rahman, Badar Ashraf, Changjun Zheng and Munni Begu. (2017). Impact of Cost Efficiency on Bank Capital and the Cost of Financial Intermediation: Evidence from BRICS Countries. Int. J. Financial Stud. 2017.

Mthuli Ncube. (2009). EFFICIENCY OF THE BANKING SECTOR IN SOUTH AFRICA . 9-12.

Musonda, A. (2008). AN INVESTIGATION INTO THE DETERMINANTS OF COST EFFICIENCY IN THE 
ZAMBIAN BANKING SECTOR. AN INVESTIGATION INTO THE DETERMINANTS OF COST EFFICIENCY IN THE ZAMBIAN BANKING SECTOR .

N.Gujarati, D. ((2004)). Basic Econometrics 4th edtion. The MGraw-Hill Campanies, 2004.

Nader A.r, Mayssa E. ,Israa W.and Reda S. (2017). Concepts, Drivers, Measures, Literature and Conceptual Model. Banking Efficiency, 4.

Nazneen F. (2019). Efficiency and Productivity of Commercial Banks: Evidence from Bangladesh, 196-97.

NBE. (2007/08). Annual report, 58.

NBE. $(2013 / 14)$.

NBE. (2017/2018). Annual Report. National Bank of Ethiopia Annual Report, 45.

NBE. (2018/19,P 5).

Nyoike, C. W. (2015,p 9). EXPANSION STRATEGIES USED BY STANDARD CHARTERED BANK TO ENHANCE COMPETITIVEADVANTAGE IN EAST AFRICAN MARKET. EXPANSION STRATEGIES USED BY STANDARD CHARTERED BANK TO ENHANCE COMPETITIVEADVANTAGE IN EAST AFRICAN MARKET, 9.

R.Hamiltona. (2010). (R.Hamiltona, Cost and Profit Efficiency in the Jordanian Banking Sector 1993-2006: A Parametric Approach, 2010,) (R.Hamiltona, Cost and Profit Efficiency in the Jordanian Banking Sector 1993-2006: A Parametric Approach, 2010.

R.Hamiltona. (2010). Cost and Profit Efficiency in the Jordanian Banking Sector 1993-2006: A Parametric Approach .

R.Hamiltona. (2015 p,99). Cost and Profit Efficiency in the Jordanian Banking Sector 1993-2006. 99.

Raphael. (2013). Efficiency of Commercial Banks in East Africa: A Non Parametric Approach. 56.

Raphael, G. (2013). Bank-specific, industry-specific and macroeconomic determinants of bank efficiency in Tanzania: A two stage analysis. .

Sanderson A, Alex B\& Pierre Le R . (2019). Evaluating Bank Cost Efficiency Using Stochastic Frontier Analysis. Journal of Economics and Behavioral Studies (ISSN: 2220-6140) Vol. 11, No. 3, pp. 48-57, June 2019 .

Shashigo, K. (2016). Determinants of Efficiency of Commercial Banks in Ethiopia. PDF, 3.

sova., B. i. (2008/2009). Measuring Bank Efficiency. Bc.Zuzana ir sova, 3.

Taci, S. and Anita. ( 2004,p 6). Cost efficiency of banks in transition: Evidence from 289 banks in 15 postcommunist countries. Working paper No. 86, 6 .

Teka, E. (2019). The Impact of Branch Expansion on Deposit Mobilization, Loan Disbursement and Profitability 30 .

Teklebeirhan. (2008). "Financial Sector Development in Ethiopia: Trend and Risks", in Birritu special publication N0. 100, Addis Ababa. 5.

Tesfaye \& Abdurezak . (2017). Cost Efficiency of Ethiopian Banks. ISSN 2222-1697 (Paper) ISSN 2222-2847 (Online) Vol.8, No.11, 2017, 36.

The concept of efficiency as a general performance indicator for all types of businesses was first formulated in the early works of Edgeworth (1881) and Pareto (1927) and recorded its empirical implementation in the book of Shephard (1953). Efficiency in . (n.d.).

Thilakaweera, B. H. (2016). Thilakaweera, B., Harvie, C. \& Arjomandi, A. (2016). Branch expansion and banking efficiency in Sri Lanka's post-conflict era. Journal of Asian Economics, 45-57. 2016 P-1, 18.

Varesi, L. (March 2015). Measuring Banking Efficiency during Crisis Period Using Data Envelopment Analysis: Western Balkan Countries Case, 263.

Varesi, L. (March 2015). Measuring Banking Efficiency during Crisis Period Using Data Envelopment Analysis: Western Balkan Countries Case. E-ISSN 2281-4612, 262-263.

Verbeek, M. (2004,p 97). A Guide to Modern Econometrics. Erasmus University Rotterdam: John Wiley \& Sons Ltd, The Atrium, Southern Gate, Chichester, West Sussex PO19 8SQ, England . 


\section{Appendices}

Appendix-1 Regression output

\begin{tabular}{|c|c|c|c|c|c|c|c|c|}
\hline r & Coef. & St.Err. & t-value & p-value & \multicolumn{2}{|c|}{ [95\% Conf } & Interval] & Sig \\
\hline $\ln w 1$ & 0.180 & 0.023 & 7.77 & 0.000 & \multicolumn{2}{|l|}{0.135} & 0.226 & $* * *$ \\
\hline $\ln W 2$ & -0.894 & 0.484 & -1.85 & 0.065 & \multicolumn{2}{|l|}{-1.843} & 0.056 & $*$ \\
\hline $\ln w 3$ & 0.022 & 0.011 & 1.95 & 0.051 & \multicolumn{2}{|l|}{0.000} & 0.044 & $*$ \\
\hline lnw4 & 0.039 & 0.014 & 2.83 & 0.005 & \multicolumn{2}{|l|}{0.012} & 0.066 & $* * *$ \\
\hline $\operatorname{lny} 1$ & 0.477 & 0.043 & 11.04 & 0.000 & \multicolumn{2}{|l|}{0.392} & 0.562 & $* * *$ \\
\hline $\ln y 2$ & 0.024 & 0.022 & 1.09 & 0.275 & \multicolumn{2}{|l|}{-0.019} & 0.068 & \\
\hline lnliquditrisk & 0.047 & 0.034 & 1.36 & 0.175 & \multicolumn{2}{|l|}{-0.021} & 0.114 & \\
\hline lnmagtperfo & -0.006 & 0.012 & -0.53 & 0.600 & \multicolumn{2}{|l|}{-0.029} & 0.017 & \\
\hline marketshare & 4.235 & 0.752 & 5.63 & 0.000 & \multicolumn{2}{|l|}{2.761} & 5.709 & $* * *$ \\
\hline Ginflation & 0.004 & 0.005 & 0.77 & 0.441 & \multicolumn{2}{|l|}{-0.006} & 0.013 & \\
\hline lnrealGDPgth & -0.009 & 0.056 & -0.16 & 0.870 & \multicolumn{2}{|l|}{-0.120} & 0.101 & \\
\hline $\operatorname{lnCAR}$ & -0.269 & 0.096 & -2.81 & 0.005 & \multicolumn{2}{|l|}{-0.457} & -0.082 & $* * *$ \\
\hline Constant & 2.047 & 0.134 & 15.23 & 0.000 & \multicolumn{2}{|l|}{1.783} & 2.310 & $* * *$ \\
\hline Mean dependent var & \multicolumn{2}{|c|}{2.994} & \multicolumn{2}{|c|}{ SD dependent var } & \multicolumn{3}{|c|}{0.297} & \\
\hline Overall r-squared & \multicolumn{2}{|c|}{0.909} & \multicolumn{2}{|c|}{ Number of obs } & \multicolumn{3}{|c|}{126.000} & \\
\hline Chi-square & \multicolumn{2}{|c|}{1132.182} & \multicolumn{2}{|c|}{ Prob $>$ chi 2} & \multicolumn{3}{|c|}{0.000} & \\
\hline R-squared within & \multicolumn{2}{|c|}{0.823} & \multicolumn{2}{|c|}{ R-squared between } & \multicolumn{3}{|c|}{0.977} & \\
\hline
\end{tabular}

$* * * p<0.01, * * p<0.05, * p<0.1$

Sources: Author own stata14 calculation

Appendix-2 Regression output

- asdoc hausman fe re

(File Myfile.doc already exists, option append was assumed)

\begin{tabular}{|c|c|c|c|c|}
\hline & \multicolumn{2}{|c|}{ Coefficients } & \multirow{3}{*}{$\begin{array}{c}(b-B) \\
\text { Difference }\end{array}$} & \multirow{3}{*}{$\begin{array}{c}\operatorname{sqrt}\left(\operatorname{diag}\left(V_{-} b-V_{-} B\right)\right) \\
\text { S.E. }\end{array}$} \\
\hline & (b) & (B) & & \\
\hline & $\mathrm{fe}$ & re & & \\
\hline lnw1 & .1442873 & .1802488 & -.0359614 & .0161768 \\
\hline $\ln 12$ & -.0450264 & -.8936029 & .8485765 & .3316847 \\
\hline $\ln 33$ & -.028312 & .0219307 & -.0502427 & .0303594 \\
\hline $\ln w 4$ & .0477962 & .0390023 & .0087939 & .0068093 \\
\hline lny 1 & .4698182 & .4769307 & -.0071125 & .0147022 \\
\hline lny2 & .019667 & .0244096 & -.0047426 & .019526 \\
\hline lnliquditr $\sim k$ & .0251077 & .046535 & -.0214273 & .0080789 \\
\hline lnmagtperfo & -.0015751 & -.006084 & .0045089 & .0182611 \\
\hline marketshare & 4.242309 & 4.234941 & .0073677 & .3548584 \\
\hline Ginflation & .0053756 & .003587 & .0017886 & . \\
\hline InrealGDPgth & .0128766 & -.0092029 & .0220795 & . \\
\hline InCAR & -.3149839 & -.2694665 & -.0455174 & .0715561 \\
\hline
\end{tabular}

$\mathrm{b}=$ consistent under $\mathrm{Ho}$ and Ha; obtained from xtreg $B=$ inconsistent under $\mathrm{Ha}$, efficient under Ho; obtained from xtreg

Test: Ho: difference in coefficients not systematic

$$
\begin{aligned}
\operatorname{chi2}(12) & =(b-B) \cdot\left[\left(V_{-} b-V_{-} B\right)^{\wedge}(-1)\right](b-B) \\
& =22.74 \\
\text { Prob }>\text { chi2 } & =0.0300 \\
\left(V_{-} b-V_{-} B\right. & \text { is not positive definite })
\end{aligned}
$$

Sources: Author own stata14 calculation 
Appendix-3 Regression output

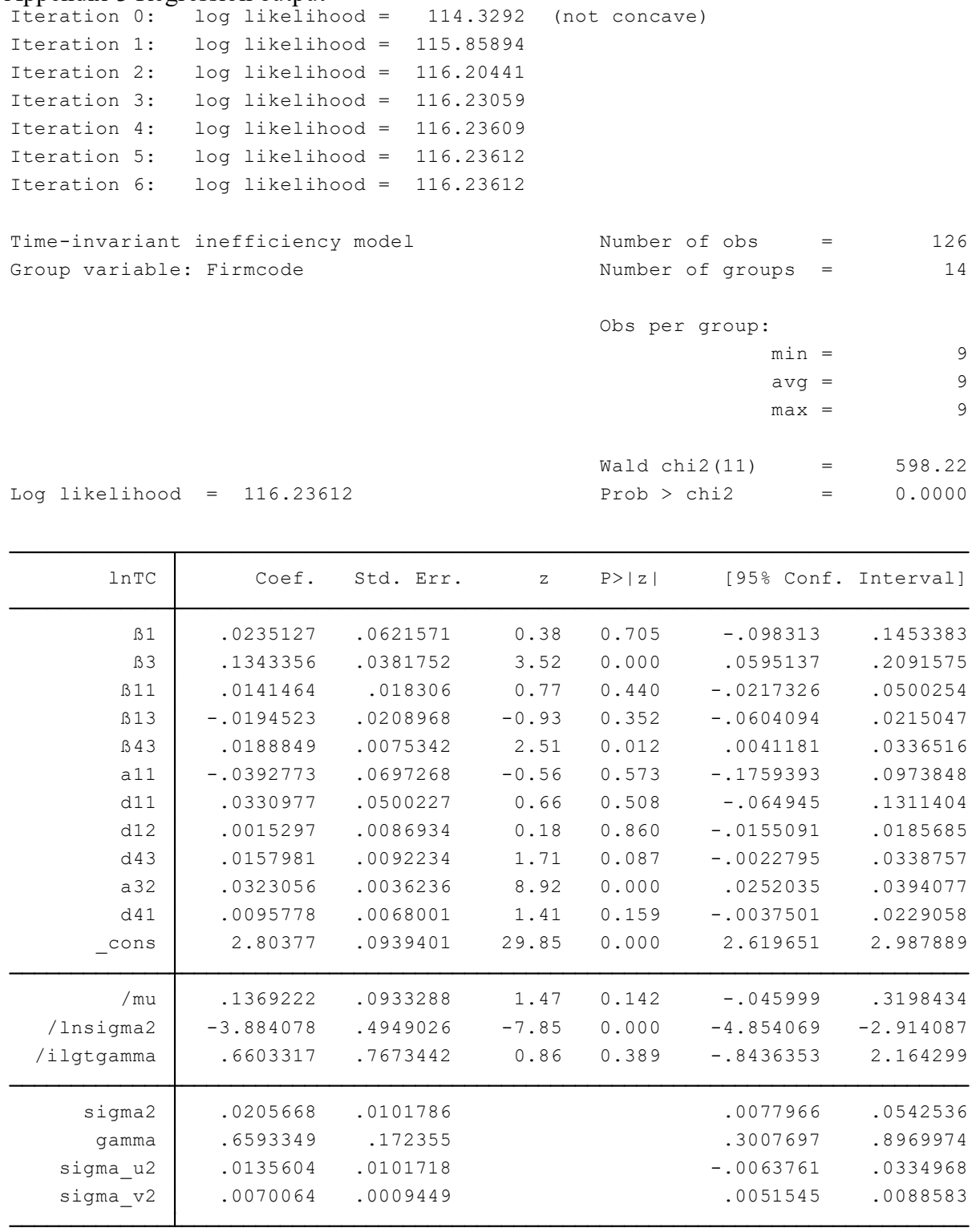

Sources: Author own stata14 calculation 


\begin{tabular}{|c|c|c|c|c|c|c|c|}
\hline Coeff & Coef. & St.Err. & $\begin{array}{l}\mathrm{t}- \\
\text { value }\end{array}$ & $\mathrm{p}$-value & [95\% Conf & Interval] & Sig \\
\hline $\ln w 1$ & -0.049 & 0.001 & -47.63 & 0.000 & -0.051 & -0.047 & $* * *$ \\
\hline $\ln W 2$ & 0.298 & 0.021 & 13.90 & 0.000 & 0.256 & 0.340 & $* * *$ \\
\hline $\ln w 3$ & -0.007 & 0.000 & -13.79 & 0.000 & -0.008 & -0.006 & $* * *$ \\
\hline $\ln w 4$ & -0.012 & 0.001 & -19.93 & 0.000 & -0.013 & -0.011 & $* * *$ \\
\hline $\operatorname{lny} 1$ & -0.137 & 0.002 & -71.63 & 0.000 & -0.141 & -0.133 & $* * *$ \\
\hline $\ln y 2$ & -0.008 & 0.001 & -7.96 & 0.000 & -0.010 & -0.006 & $* * *$ \\
\hline Inliquditrisk & -0.016 & 0.002 & -10.39 & 0.000 & -0.019 & -0.013 & $* * *$ \\
\hline lnmagtperfo & 0.003 & 0.001 & 5.01 & 0.000 & 0.002 & 0.004 & $* * *$ \\
\hline marketshare & -0.129 & 0.033 & -3.88 & 0.000 & -0.195 & -0.064 & $* * *$ \\
\hline Ginflation & -0.001 & 0.000 & -3.76 & 0.000 & -0.001 & 0.000 & $* * *$ \\
\hline lnrealGDPgth & 0.004 & 0.002 & 1.67 & 0.095 & -0.001 & 0.009 & $*$ \\
\hline $\operatorname{lnCAR}$ & 0.069 & 0.004 & 16.31 & 0.000 & 0.061 & 0.077 & $* * *$ \\
\hline Constant & 1.185 & 0.006 & 199.07 & 0.000 & 1.173 & 1.197 & $* * *$ \\
\hline Mean dependent var & & 0.920 & SD de & ndent var & 0.06 & & \\
\hline Overall r-squared & & 0.996 & Numbe & of obs & 126. & & \\
\hline Chi-square & & 29471.969 & Prob $>$ & 112 & 0.00 & & \\
\hline R-squared within & & 0.993 & R-squa & d between & 0.99 & & \\
\hline
\end{tabular}

$* * * p<0.01, * * p<0.05, * p<0.1$

Sources: Author own statal 4 calculation

Appendix-7 Regression outputresults

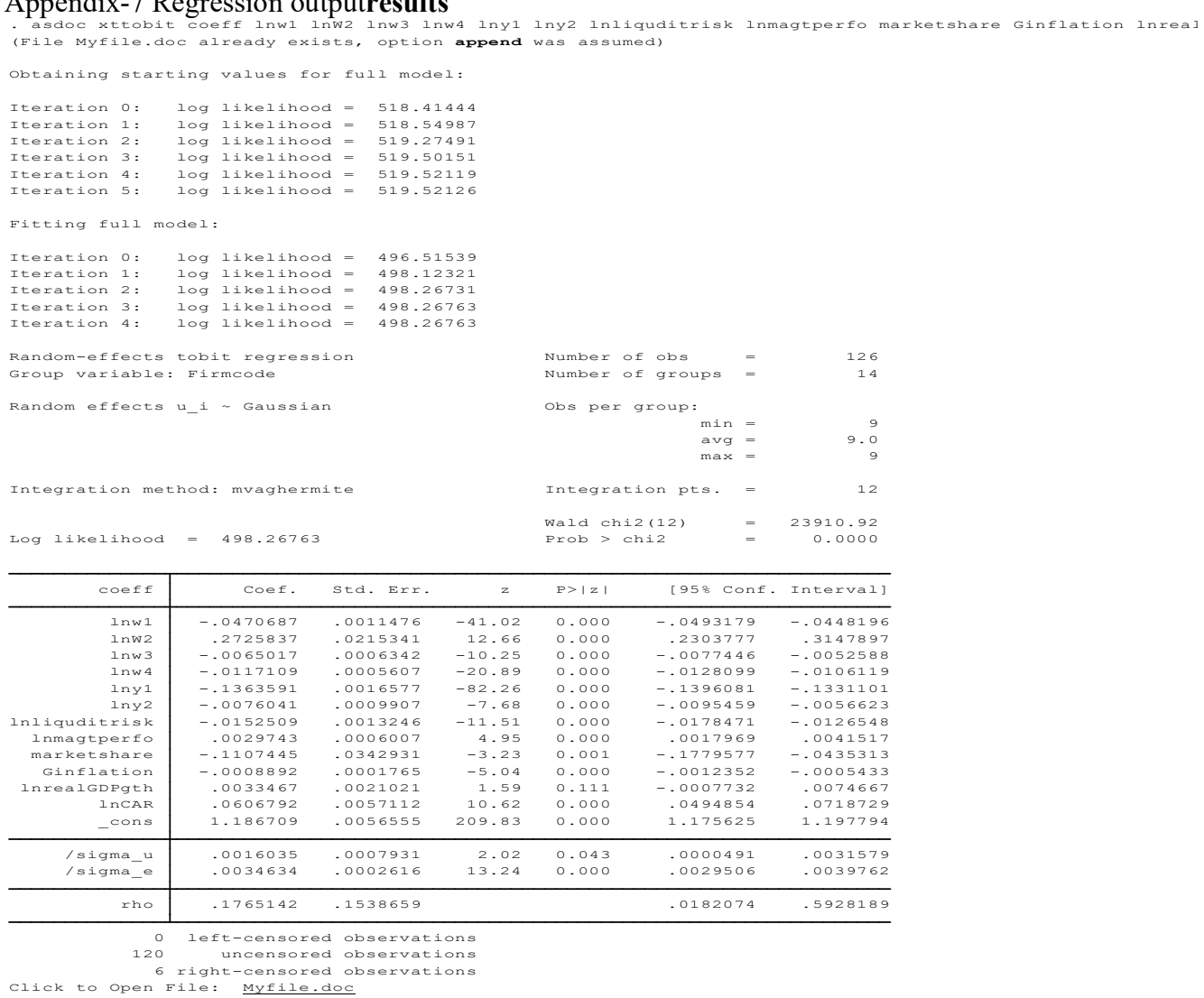

Sources: Author own stata14 calculation 
Appendix-5 Cost Efficiency Scores of Commercial Banks (Fiscal Year 2010/11-20118/19)

\begin{tabular}{|l|l|l|l|l|l|l|l|l|l|l|}
\hline Bank & $\mathbf{2 0 1 0} / \mathbf{1 1}$ & $\mathbf{2 0 1 1} / \mathbf{1 2}$ & $\mathbf{2 0 1 2} / \mathbf{1 3}$ & $\mathbf{2 0 1 3} / \mathbf{1 4}$ & $\mathbf{2 0 1 4} / \mathbf{1 5}$ & $\mathbf{2 0 1 5} / \mathbf{1 6}$ & $\mathbf{2 0 1 6} / \mathbf{1 7}$ & $\mathbf{2 0 1 7} / \mathbf{1 8}$ & $\mathbf{2 0 1 8} / \mathbf{1 9}$ & rank \\
\hline CBE & 0.862 & 0.833 & 0.797 & 0.769 & 0.745 & 0.726 & 0.707 & 0.702 & 0.680 & 14 \\
\hline AB & 0.945 & 0.949 & 0.934 & 0.920 & 0.902 & 0.880 & 0.865 & 0.840 & 0.808 & 12 \\
\hline DB & 0.952 & 0.950 & 0.929 & 0.910 & 0.902 & 0.877 & 0.874 & 0.845 & 0.827 & 11 \\
\hline BOA & 0.985 & 0.963 & 0.954 & 0.933 & 0.932 & 0.901 & 0.877 & 0.842 & 0.837 & 9 \\
\hline WB & 0.996 & 1.000 & 0.974 & 0.956 & 0.942 & 0.920 & 0.909 & 0.879 & 0.853 & 7 \\
\hline UB & 0.972 & 0.971 & 0.949 & 0.937 & 0.942 & 0.913 & 0.887 & 0.870 & 0.842 & 8 \\
\hline NIB & 0.982 & 0.944 & 0.972 & 0.986 & 0.956 & 0.909 & 0.879 & 0.886 & 0.857 & 6 \\
\hline OIB & 0.924 & 0.928 & 0.945 & 0.956 & 0.935 & 0.913 & 0.882 & 0.862 & 0.803 & 10 \\
\hline LIB & 1.021 & 1.015 & 0.990 & 0.969 & 0.962 & 0.945 & 0.921 & 0.898 & 0.876 & 3 \\
\hline OIB & 1.005 & 1.016 & 1.003 & 1.003 & 0.980 & 0.952 & 0.943 & 0.884 & 0.867 & 4 \\
\hline ZEB & 0.975 & 0.999 & 0.986 & 0.982 & 0.971 & 0.960 & .943 & 0.932 & 0.906 & 1 \\
\hline BUB & 1.004 & 1.023 & 0.993 & 0.981 & 0.964 & 0.932 & 0.935 & 0.908 & 0.884 & 2 \\
\hline BIB & 0.961 & 0.986 & 0.970 & 0.967 & 0.979 & 0.978 & 0.935 & 0.911 & 0.871 & 5 \\
\hline ABAY & 0.974 & 0.989 & 0.982 & 0.950 & 0.963 & 0.951 & 0.935 & 0.888 & 0.894 & 13 \\
\hline
\end{tabular}

Sources: Author own stata14 calculation 